\title{
Mechanistic Investigation of GHS-R Mediated Glucose-Stimulated Insulin Secretion in Pancreatic Islets
}

\author{
Geetali Pradhan ${ }^{1,2}$, Jong Han Lee ${ }^{1,3}$, Chia-Shan Wu ${ }^{4}\left(\mathbb{D}\right.$, Hongying Wang ${ }^{4}$, Ligen Lin ${ }^{1,5}$ (D), Taraka Donti ${ }^{6,7}$, \\ Brett H. Graham ${ }^{6,8}$, Arun S. Rajan ${ }^{9}$, Ashok Balasubramanyam ${ }^{9}$, Susan L. Samson ${ }^{9} \mathbb{D}$, Shaodong Guo ${ }^{4}$ \\ and Yuxiang Sun 1,4,*
}

\section{check for} updates

Citation: Pradhan, G.; Lee, J.H.; Wu, C.-S.; Wang, H.; Lin, L.; Donti, T.; Graham, B.H.; Rajan, A.S.; Balasubramanyam, A.; Samson, S.L.; et al. Mechanistic Investigation of GHS-R Mediated Glucose-Stimulated Insulin Secretion in Pancreatic Islets. Biomolecules 2022, 12, 407. https:// doi.org/10.3390/biom12030407

Academic Editors: Myron R. Szewczuk and David E. Stec

Received: 30 December 2021 Accepted: 27 February 2022 Published: 6 March 2022

Publisher's Note: MDPI stays neutral with regard to jurisdictional claims in published maps and institutional affiliations.

Copyright: (C) 2022 by the authors. Licensee MDPI, Basel, Switzerland. This article is an open access article distributed under the terms and conditions of the Creative Commons Attribution (CC BY) license (https:// creativecommons.org/licenses/by/ $4.0 /)$.
1 USDA/ARS Children's Nutrition Research Center, Department of Pediatrics, Baylor College of Medicine, Houston, TX 77030, USA; gpradhan@purdue.edu (G.P.); jhleecw@gmail.com (J.H.L.); ligenl@um.edu.mo (L.L.)

2 Interdepartmental Program in Translational Biology and Molecular Medicine, Baylor College of Medicine, Houston, TX 77030, USA

3 Department of Marine Bioindustry, Hanseo University, Seosan 31962, Korea

4 Department of Nutrition, Texas A\&M University, College Station, TX 77843, USA; chiashan.wu@ag.tamu.edu (C.-S.W.); hongying.wang@ag.tamu.edu (H.W.); shaodong.guo@tamu.edu (S.G.)

5 State Key Laboratory of Quality Research in Chinese Medicine, Institute of Chinese Medical Sciences, University of Macau, Macau 999078, China

6 Department of Molecular and Human Genetics, Baylor College of Medicine, Houston, TX 77030, USA; taraka.donti@perkinelmer.com (T.D.); bregraha@iu.edu (B.H.G.)

7 PerkinElmer Genomics, 250 Industry Dr., Pittsburgh, PA 15275, USA

8 Department of Medical \& Molecular Genetics, Indiana University School of Medicine, Indianapolis, IN 46202, USA

9 Department of Medicine, Baylor College of Medicine, Houston, TX 77030, USA; arajan@bcm.edu (A.S.R.); ashokb@bcm.edu (A.B.); samson.susan@mayo.edu (S.L.S.)

* Correspondence: yuxiang.sun@tamu.edu; Tel.: +1-979-862-9143

Abstract: Ghrelin receptor, a growth hormone secretagogue receptor (GHS-R), is expressed in the pancreas. Emerging evidence indicates that GHS-R is involved in the regulation of glucose-stimulated insulin secretion (GSIS), but the mechanism by which GHS-R regulates GSIS in the pancreas is unclear. In this study, we investigated the role of GHS-R on GSIS in detail using global $\mathrm{Ghsr}^{-/-}$mice (in vivo) and Ghsr-ablated pancreatic islets (ex vivo). GSIS was attenuated in both $\mathrm{Ghsr}^{-/-}$mice and Ghsr-ablated islets, while the islet morphology was similar between WT and Ghsr-/- mice. To elucidate the mechanism underpinning Ghsr-mediated GSIS, we investigated the key steps of the GSIS signaling cascade. The gene expression of glucose transporter 2 (Glut2) and the glucose-metabolic intermediate-glucose-6-phosphate (G6P) were reduced in Ghsr-ablated islets, supporting decreased glucose uptake. There was no difference in mitochondrial DNA content in the islets of WT and $\mathrm{Ghsr}^{-/-}$mice, but the ATP/ADP ratio in $\mathrm{Ghsr}^{-/-}$islets was significantly lower than that of WT islets. Moreover, the expression of pancreatic and duodenal homeobox $1(\mathrm{Pdx} 1)$, as well as insulin signaling genes of insulin receptor (IR) and insulin receptor substrates 1 and 2 (IRS1/IRS2), was downregulated in $\mathrm{Ghsr}^{-/}$islets. Akt is the key mediator of the insulin signaling cascade. Concurrently, Akt phosphorylation was reduced in the pancreas of $\mathrm{Ghsr}^{-/-}$mice under both insulin-stimulated and homeostatic conditions. These findings demonstrate that GHS-R ablation affects key components of the insulin signaling pathway in the pancreas, suggesting the existence of a cross-talk between GHS-R and the insulin signaling pathway in pancreatic islets, and GHS-R likely regulates GSIS via the Akt-Pdx1-GLUT2 pathway.

Keywords: growth hormone secretagogue receptor (GHS-R); glucose-stimulated insulin secretion (GSIS); glucose transporter 2 (Glut2); pancreatic and duodenal homeobox 1 (Pdx1); insulin; islets

\section{Introduction}

Glucose-stimulated insulin secretion (GSIS) is a tightly regulated process, and GSIS impairment is a hallmark of type 2 diabetes (T2D). Ghrelin is a peptide hormone secreted 
mainly from the oxyntic cells of the stomach [1,2]; it is also expressed in other cells, including the $\alpha, \beta$, and $\varepsilon$-cells in pancreatic islets [3-7]. Further, ghrelin expression in the stomach can be regulated by both cholinergic and adrenergic arms of the autonomic nervous system [8]. Ghrelin has been reported to inhibit GSIS in the pancreas, isolated pancreatic islets, and $\beta$-cells [6,9-12]. Growth hormone secretagogue receptor (GHS-R) is the only recognized receptor for ghrelin to date [2]. GHS-R is primarily expressed in the brain and pituitary gland where it mediates ghrelin's effects on food intake and growth hormone secretion [13]. GHS-R is also expressed in the $\alpha, \beta, \gamma$, and $\delta$-cells of pancreatic islets [13-19]. GHS-R mediates ghrelin-induced inhibition of insulin secretion [20], as well as the induction of glucagon [21] and somatostatin [22] in the pancreas. Various pathways have been proposed to mediate the inhibition of insulin secretion by the ghrelin-GHS-R signaling. Dezaki et al. demonstrated that ghrelin uses $\mathrm{G} \alpha_{\mathrm{i} / \mathrm{o}}$ to activate voltage-dependent $\mathrm{K}^{+}$channels to inhibit $\left[\mathrm{Ca}^{2+}\right]_{\mathrm{I}}$ and insulin release [23]. Roy et al. showed that GHS-R activation leads to its coupling to $\mathrm{G} \alpha_{\mathrm{i} / \mathrm{o}}$ but requires heterodimerization with somatostatin receptor-5 (SSTR5) to transduce ghrelin's inhibitory tone on insulin secretion [24]. Another study suggested that ghrelin interacts with GHS-R in $\beta$-cells to attenuate glucose-induced $\left[\mathrm{Ca}^{2+}\right]_{i}$ and insulin release via the cAMP-TRPM2 pathway [25]. Interestingly, our studies in ghrelin $^{-/-}$and $\mathrm{Ghsr}^{-/-}$mice showed that the ablation of ghrelin and GHS-R have distinctive effects on insulin secretion [26-28], which raises the question of whether ghrelin and GHS-R activate the differential signaling pathways in pancreatic $\beta$ cells.

It has been widely debated whether insulin itself affects $\beta$ cell function and if $\beta$ cell insulin secretion is insulin-dependent. Studies using animal models, isolated islets, and cell lines have suggested that the pancreas is insulin-responsive, and insulin signaling pathways modulate $\beta$-cell functions [29]. It has been reported that insulin stimulates GSIS in the $\beta$-cells of humans [30] and rodents [31]. It has also been shown that only healthy individuals [32], not glucose tolerant/insulin-resistant individuals [33,34], are responsive to insulin in GSIS tests. Remarkably, animal data further revealed that $\beta$-cell specific insulin receptor knockout ( $\beta$ IRKO) mice exhibit reduced GSIS [35]; the deletion of insulin signaling proteins, such as IRS-1, IRS-2, Phosphoinositide 3-kinases (PI3K), and Protein kinase B (Akt) 2 , affects insulin secretion and glucose sensing [36-39]. Glucose transporter 2 (GLUT2) is a key protein for glucose sensing in $\beta$-cells, and Glut2 knockout mice exhibit hyperglycemia, impaired glucose tolerance, and impaired GSIS [40]. Despite these exciting findings, it is still not fully understood whether insulin signaling regulates GSIS in $\beta$-cells. Intriguingly, as nutrient-sensing regulators, both ghrelin and GHS-R have been reported to be associated with insulin resistance [27,41-44]. GHS-R has been shown to modulate the IRS1-PI3K-Akt signaling pathway in 3T3-L1 preadipocytes [45,46] and hepatoma cells [47]. However, it is unknown whether GHS-R has a similar effect on GSIS as ghrelin and whether insulin signaling mediates GHS-R-associated GSIS regulation in pancreatic islets by modulating insulin signaling.

In the current study, we used global Ghsr-/- mice and the Ghsr-ablated pancreatic islets to investigate the molecular mechanisms by which GHS-R regulates GSIS in pancreatic islets.

\section{Materials and Methods}

\subsection{Animals}

Animals were housed under controlled temperature and lighting cycles $\left(75 \pm 1^{\circ} \mathrm{F}\right.$; $12 \mathrm{~h}$ light-dark cycle) with free access to regular mouse chow and water. Ghsr ${ }^{-/-}$mice in a C57BL/6J background were generated and characterized as we previously described, which were backcrossed to a C57BL/6J background for 15 generations [13]. All mice used in the experiments were age-matched congenic males unless otherwise indicated. We only used male mice in our study to eliminate insulin variation associated with menstrual cycles of female mice [48]. All mice were housed and bred in a pathogen-free facility at Baylor College of Medicine, and the animal protocol was approved by the Animal Care Research Committee at the Baylor College of Medicine. 


\subsection{Glucose Stimulated Insulin Secretion (GSIS) In Vivo}

Mice were fasted overnight $(16 \mathrm{~h})$ and then intraperitoneally (i.p.) injected with $3 \mathrm{~g} / \mathrm{kg}$ body weight glucose. Blood glucose was measured at $0,2,5,15$, and $30 \mathrm{~min}$, and insulin was measured at $0,2,5,15$, and $30 \mathrm{~min}$ after glucose administration. Glucose was measured using OneTouch Ultra2 glucometer (LifeScan Inc., Milpitas, CA, USA). Insulin was measured using Mouse Insulin ELISA kit (Mercodia, Uppsala, Sweden) per the manufacturer's instructions.

\subsection{Immunohistochemistry of Pancreas}

Immunostaining was performed on pancreatic sections fixed in formalin and paraffinembedded by the Texas Medical Center Digestive Diseases Center, Cellular and Molecular Morphology core. The glucagon antibody (Cat\# PA0594) and insulin antibody (2D11-H5, Cat\# Pa0620) were obtained from Leica Biosystems (Wetzlar, Germany). The image in the manuscript is representative of $12-14$ islets/mouse, 3 mice/genotype.

\subsection{Islet Isolation}

The islets were collected using the collagenase method, digested with collagenase $\mathrm{P}$ (Roche, Basel, Switzerland) and then were cultured overnight, as we and others have described [49,50]. Briefly, $3 \mathrm{~mL}$ of $1 \mathrm{mg} / \mathrm{mL}$ collagenase $\mathrm{P}$ was injected with a 27G needle into the ampulla of Vater of the pancreas. The digested pancreas was then removed and placed in a $50 \mathrm{~mL}$ tube containing $2 \mathrm{~mL}$ of the collagenase solution. The tube was subsequently placed in $37^{\circ} \mathrm{C}$ shaking water bath shaking at $100-120 \mathrm{rpm}$ speed for 12-13 min until the solution became homogenous. Cold Hank's Balanced Salt Solution $(20 \mathrm{~mL})$ was later added to stop digestion. The tubes were centrifuged at $290 \times \mathrm{g}$ for $30 \mathrm{~s}$ at $4{ }^{\circ} \mathrm{C}$, and the supernatant decanted. This procedure was repeated 3 more times; the islets were then separated from the acinar tissue using a Ficoll gradient Histopaque-1077 (Sigma-Aldrich, Kawasaki, Japan) per the manufacturer's instructions. The islets were subsequently hand-picked under a microscope and incubated overnight in RPMI 1640 medium containing $5.5 \mathrm{mM}$ glucose at $37^{\circ} \mathrm{C}$. The next day, the medium was replaced with Hanks' Balanced Salt solution (HBSS) pH 7.2, consisting of $114 \mathrm{mM} \mathrm{NaCl}, 4.7 \mathrm{mM} \mathrm{KCl}$, $1.2 \mathrm{mM} \mathrm{KH}_{2} \mathrm{PO}_{4}, 1.16 \mathrm{mM} \mathrm{MgSO}_{4}, 20 \mathrm{mM}$ HEPES, $2.5 \mathrm{mM} \mathrm{CaCl}_{2}, 25.5 \mathrm{mM} \mathrm{NaHCO}_{3}{ }^{\prime} 0.2 \%$ bovine serum albumin, and $3.3 \mathrm{mM}$ glucose, and incubated for $2 \mathrm{~h}$ at $37^{\circ} \mathrm{C}$ before assessing GSIS ex vivo [51].

\subsection{Glucose-Stimulated Insulin Secretion (GSIS)}

After overnight recovery in RPMI (5.5 mM glucose), the islets were placed in HBSS solution containing $3.3 \mathrm{mM}$ glucose for $2 \mathrm{~h}$. Then, 10 similar-sized islets were hand-picked and placed in each well of a 24-well plate. There were 8-12 wells per treatment/genotype in each experiment. The islets were incubated in $500 \mu \mathrm{L}$ HBSS containing $3.3 \mathrm{mM}, 11.1 \mathrm{mM}$, or $22.2 \mathrm{mM}$ glucose, and the plate was placed in a $37^{\circ} \mathrm{C}$ incubator for $2 \mathrm{~h}$. After $2 \mathrm{~h}$, the supernatant was saved for insulin measurement, and the islets in each well were picked to measure protein content. The insulin secreted in the supernatant was normalized to the protein content in islets.

\subsection{Insulin Content of Pancreas and Islets}

For the total insulin content of the pancreas, the whole tissue was weighed and then homogenized in $3 \mathrm{~mL}$ of ice-cold acid-ethanol, containing 70\% (v/v) ethanol and 5\% $(v / v)$ $\mathrm{HCl}$. The tubes were then held at $4{ }^{\circ} \mathrm{C}$ for $24 \mathrm{~h}$. After $24 \mathrm{~h}, 2 \mathrm{~mL}$ ice-cold acid-ethanol was added to the tubes, tissue was homogenized, and tubes were held at $4{ }^{\circ} \mathrm{C}$ for another $24 \mathrm{~h}$. On day 3 , tubes were centrifuged at $2400 \mathrm{rpm}$ for $30 \mathrm{~min}$ at $4{ }^{\circ} \mathrm{C}$, and the supernatant was saved for insulin measurement. The insulin content was normalized to the weight of the pancreas. For the insulin content of islets, 15 pancreatic islets were homogenized using $100 \mu \mathrm{L}$ of ice-cold acid-ethanol. A total of $10 \mu \mathrm{L}$ of the lysate was used to measure the protein content using a Bradford assay. The remaining lysate was held at $4{ }^{\circ} \mathrm{C}$ for $24 \mathrm{~h}$. 
After $24 \mathrm{~h}$, the tubes were centrifuged at $12,000 \mathrm{rpm}$ for $15 \mathrm{~min}$ at $4{ }^{\circ} \mathrm{C}$, and the supernatant was saved for insulin measurement. The insulin content in the islets was normalized to the protein content and the number of islets.

\subsection{Respirometry of Islets}

The Seahorse XF24 Extracellular Flux Analyzer (Seahorse Bioscience, Copenhagen, Denmark) was used to assess a range of metabolic parameters through real-time monitoring of the cellular Oxygen Consumption Rate (OCR). Islets were isolated and incubated overnight in RPMI supplemented with $5.5 \mathrm{mM}$ glucose. On the day of the assay, the islets were incubated in HBSS buffer containing either $3.3 \mathrm{mM}$ glucose or $22.2 \mathrm{mM}$ glucose for $2 \mathrm{~h}$. Then, the islets were washed in a $50 \mathrm{~mL}$ tube containing Seahorse Assay media $+3.3 \mathrm{mM}$ glucose. Then, the media was carefully removed from the $50 \mathrm{~mL}$ tube, and the islets were resuspended in another $2 \mathrm{~mL}$ of Seahorse Assay media $+3.3 \mathrm{mM}$ glucose. A total of $50-80$ islets were seeded/well in XF 24-well islet capture microplates by pipetting $2 \times 50 \mu \mathrm{L}$ of stirred islet mix into each of the 20 wells, pre-loaded with $400 \mathrm{~mL}$ of Seahorse Assay media $+3.3 \mathrm{mM}$ glucose. Four wells were kept empty as controls in every experiment. Screens were carefully put on top of the depression of all wells with tweezers. To avoid bubble formation, the screens were pre-wetted with Seahorse Assay media. The islet plate was then incubated for $60 \mathrm{~min}$ at $37^{\circ} \mathrm{C}$ without $\mathrm{CO}_{2}$, before it was loaded into the XF24 respirometry machine. Four baseline OCR measurements were taken before the following substrates/compounds were injected: $22.2 \mathrm{mM}$ glucose, $5 \mu \mathrm{M}$ oligomycin, $1 \mu \mathrm{M}$ 2-[2-[4(trifluoromethoxy)phenyl]hydrazinylidene]-propanedinitrile (FCCP), $5 \mu \mathrm{M}$ rotenone, and $5 \mu \mathrm{M}$ antimycin A. A change in OCR after $22.2 \mathrm{mM}$ glucose treatment is obtained by subtracting OCR after $22.2 \mathrm{mM}$ glucose treatment from the basal OCR value. The rate of oxygen consumption coupling to ATP production (ATP turnover) is obtained by subtracting the Oligomycin-associated OCR value from basal OCR. The data are normalized to the protein content of islets/well and are presented as $\mathrm{pmol} / \mathrm{min} / \mathrm{mg}$ protein.

\subsection{ATP/ADP Ratio}

On the day of the assay, the islets were placed in HBSS containing $1.1 \mathrm{mM}$ glucose for $2 \mathrm{~h}$. Then, 15 similar-sized islets/well were hand-picked and treated with $3.3 \mathrm{mM}$ glucose or $22.2 \mathrm{mM}$ glucose. After treatment for $2 \mathrm{~h}$, the ATP/ADP ratio was measured using ApoSENSOR ADP / ATP Ratio Bioluminescent Assay Kit (BioVision, Milpitas, CA, USA), per the manufacturer's instructions.

\subsection{Glucose-6-Phosphate Measurement}

The animals were fasted overnight for $18 \mathrm{~h}$, then injected intraperitoneally with $3 \mathrm{~g} / \mathrm{kg}$ glucose. After $1 \mathrm{~h}$, the pancreas was removed, and Glucose-6-Phosphate (G6P) was measured using Glucose-6-Phosphate Assay Kit (Sigma-Aldrich, St. Louis, MO, USA), per the manufacturer's instructions.

\subsection{Real-Time RT-PCR}

Total RNA from islets was isolated using Arcturus PicoPure RNA Isolation Kit, Cata$\log$ \# KIT0202, KIT0204 (ABI), following the manufacturer's instructions. The cDNA was synthesized from 250-500 ng RNA using the SuperScript III First-Strand Synthesis System (Invitrogen, Carlsbad, CA, USA). Real-time RT-PCR was performed on Bio-Rad Real-Time PCR Cycler (Bio-Rad Lab., Hercules, CA, USA) using SYBR Green PCR Master Mix according to the protocol provided by the manufacturer. Relative gene expression levels were normalized by $18 \mathrm{~S}$ rRNA and/or $\beta$-actin. The primers were as follows, Glut2: forward primer 5'-ATCATTGGCACATCCTACT-3', reverse primer 5'-TCAGTTCCTCTTAGTCTCTTC-3'; IR: forward primer $5^{\prime}$-CAAAAGCACAATCAGAGTGAGTATGAC-3' ${ }^{\prime}$, reverse primer $5^{\prime}-$ ACCACGTTGTGCAGGTAATCC-3 ${ }^{\prime}$; IRS-1: forward primer 5'-GCCTGGAGTATTATGAGA ACGAGAA-3', reverse primer 5'-GGGGATCGAGCGTTTGG-3'; IRS-2: forward primer $5^{\prime}$-acttccagggtccactgctg- $3^{\prime}$, reverse primer $5^{\prime}$-ggctttggaggtgccacgatag- $3^{\prime} ; \mathrm{Pdx} 1$ : forward 
primer 5'-AGAGGGGGAACGACTCTAGG-3' ${ }^{\prime}$, reverse primer 5'-ACTTGAGCGTTCCAAT ACGG-3'; MafA: forward primer 5'-CGCAGGCCACCACGTGCGCTTGGAGGAG-3' , reverse primer $5^{\prime}$-CTGCGCTGGCGAGGGCTCCCGAGGGAAG-3'. Ins 1: forward primer $5^{\prime}$ GACCAGCTATAATCAGAGACC-3' ${ }^{\prime}$, reverse primer $5^{\prime}$-AGTTGCAGTAGTTCTCCAGCTG$3^{\prime}$; Ins 2: forward primer $5^{\prime}$-AGCCCTAAGTGATCCGCTACAA-3', reverse primer $5^{\prime}$ AGTTGCAGTAG-TTCTCCAGCTG-3'.

\subsection{Western Blot}

Protein expression of PDX1 was measured from the pancreas of 5-month-old WT and $\mathrm{Ghsr}^{-/-}$mice. To measure the effects of insulin on the phosphorylation of Akt, WT, and $\mathrm{Ghsr}^{-/-}$, mice were fasted for $24 \mathrm{~h}$. Then, the mice were injected with 10U insulin or saline ip. After $5 \mathrm{~min}$, pancreatic tissue was collected for assessing protein expression of $\mathrm{p}-\mathrm{AKT}$ and $\mathrm{t}-\mathrm{AKT}$ [52]. Antibodies for $\mathrm{p}-\mathrm{Akt}$, $\mathrm{t}-\mathrm{Akt}, \mathrm{Pdx1}$, and $\beta$ actin were obtained from Cell Signaling Technologies (Beverly, MA, USA). For immunohistochemical staining, the following primary antibodies were used: rabbit anti-mouse p-Akt (1:1000), rabbit anti-mouse t-Akt (1:1000), rabbit anti-mouse pdx1 (1:1000), and rabbit anti-mouse $\beta$ actin (1:1000). Goat anti-rabbit IgG was used as a secondary antibody at a 1:200 dilution.

\subsection{Extraction and Quantification of Mitochondrial DNA}

Mitochondrial DNA (mtDNA) was extracted and quantified as described with modification [53]. Briefly, pancreatic islets were isolated and homogenized in isolation buffer (300 mM sucrose, $1 \mathrm{mM}$ EDTA, $5 \mathrm{mM}$ MOPS, $5 \mathrm{mM} \mathrm{KH2PO4,} \mathrm{0.01 \%} \mathrm{BSA,} \mathrm{pH} \mathrm{7.4)} \mathrm{in} \mathrm{a} \mathrm{glass}$ homogenizer with Teflon pestle. The homogenate was first filtered through a layer of gauze and centrifuged at $8000 \times g$ for $10 \mathrm{~min}$ at $4{ }^{\circ} \mathrm{C}$. The supernatant was discarded, and the pellet (containing cell debris, nuclei, and mitochondria) was resuspended in a small amount of isolation buffer and transferred to a new tube. Then the tube was centrifuged at $800 \times g$ for $10 \mathrm{~min}$ at $4{ }^{\circ} \mathrm{C}$, and the supernatant (containing mitochondria) was carefully transferred to a new tube, and the pellet containing the nuclei (including cell debris) was saved. The new supernatant was then further centrifuged at higher speed of $8000 \times g$ for $10 \mathrm{~min}$ at $4{ }^{\circ} \mathrm{C}$, and the resulting mitochondria pellet was saved. The nuclear DNA was extracted with the phenol/chloroform method [54]. An aliquot of the mitochondrial fraction was digested overnight in lysis buffer (10 mM Tris, $\mathrm{pH}$ 8.0, $10 \mathrm{mM}$ EDTA, $10 \mathrm{mM} \mathrm{NaCl}, 0.5 \%$ SDS, $100 \mathrm{mg} / \mathrm{mL}$ Proteinase $\mathrm{K}$ ) at $37^{\circ} \mathrm{C}$, and then boiled for $5 \mathrm{~min}$. The mitochondrial DNA was linearized by digestion with Bcl-I for $3 \mathrm{~h}$ at $50{ }^{\circ} \mathrm{C}$ and then boiled for $5 \mathrm{~min}$. The samples were centrifuged at $7000 \times g$ for $5 \mathrm{~min}$, and the resulting supernatant was used for subsequent PCR amplification. PCR was performed to amplify a 162-nt region of the mitochondrial NADH dehydrogenase subunit 4 gene. The primer sequences were $5^{\prime}$-TACACGATGAGGCAACCAAA- ${ }^{\prime}$ and $5^{\prime}$-GGTAGGGGGTGTGTGTTGTGAG- ${ }^{\prime}$. The PCR product was purified with the High Pure PCR template preparation kit (Roche, Indianapolis, IN). The nuclear DNA and the amplified PCR product of mitochondrial DNA (mtDNA) were quantified with NanoDrop (ND-1000 Thermo Scientific, Waltham, MA, USA), and the ratio of mtDNA/total DNA was calculated.

\subsection{Statistical Analysis}

Graph-Pad Prism version 6.0 software was used. Two-way ANOVA with repeated measures or one-way ANOVA was used. Data are represented as mean $\pm \mathrm{SEM}$, and $p<0.05$ was considered statistically significant.

\section{Results}

\subsection{GHS-R Ablation Decreases Glucose-Stimulated Insulin Secretion (GSIS)}

To access the effect of Ghsr ablation on GSIS, we performed a GSIS assay in vivo using wild-type (WT) controls and $\mathrm{Ghsr}^{-/-}$mice. Insulin secretion is biphasic, traditionally present as first and second phases. A regular glucose tolerance test $(2.0 \mathrm{~g} / \mathrm{kg}$ glucose for $2 \mathrm{~h}$ ) cannot easily distinguish between the two phases of insulin secretion patterns, so 
we performed a 30 min GSIS test using $3.0 \mathrm{~g} / \mathrm{kg}$ glucose. The blood glucose was mostly similar between WT controls and $\mathrm{Ghsr}^{-/-}$mice in the GSIS assay, except at the 2 min time point where glucose was significantly higher in $\mathrm{Ghsr}^{-/-}$mice (Figure 1A). Interestingly, insulin secretion in $\mathrm{Ghsr}^{-/-}$mice was significantly attenuated during GSIS, especially at the 5 and 15-min points (Figure 1A), which indicates that first-phase insulin secretion was decreased. We have previously reported lower fasting insulin in 6-month-old Ghsr-/mice [55]; interestingly, the 4.5-month-old $\mathrm{Ghsr}^{-/-}$mice showed similar fasting insulin at the time point of in vivo GSIS (Figure 1A). To directly assess the effect of Ghsr deletion on GSIS, pancreatic islets from WT and $\mathrm{Ghsr}^{-/-}$mice were treated with 3.3, 11.1, or $22.2 \mathrm{mM}$ glucose, and insulin levels were measured. While insulin secretion at the lowest glucose concentration $(3.3 \mathrm{mM})$ was similar between the two genotypes, the insulin secreted by $\mathrm{Ghsr}^{-/-}$islets was significantly reduced at higher glucose concentrations of 11.1 and $22.2 \mathrm{mM}$ (Figure 1B). To determine whether reduced insulin detected during GSIS was due to the low availability of insulin stored in $\beta$-cells, the islet morphology and total insulin content in the entire pancreas and isolated islets of WT and Ghsr ${ }^{-/}$mice were assessed. Grossly, no obvious difference was observed in islet size or intensity of glucagon staining in the pancreatic sections, while the insulin staining appeared to be denser in $\mathrm{Ghsr}^{-/-}$mice (Figure 1C). Rodents have two insulin genes, namely Insulin 1 and Insulin 2 [56,57], which are normally expressed in a ratio of 1:2 simultaneously [58]. To determine insulin gene expression, we assessed Insulin 1 (Ins1) and Insulin 2 (Ins2) in pancreatic islets. Intriguingly, the islet Ins1 gene expression was significantly upregulated, whereas Ins2 gene expression was significantly downregulated in $\mathrm{Ghsr}^{-/-}$mice (Figure 1D). The total insulin protein content in the pancreas and islets of $\mathrm{Ghsr}^{-/-}$mice was higher compared to WT controls (Figure 1E). Overall, these results indicate that GHS-R ablation suppresses GSIS both in vivo and ex vivo, despite the higher insulin content in the islets, which suggests that GHS-R affects insulin secretion but not insulin production.
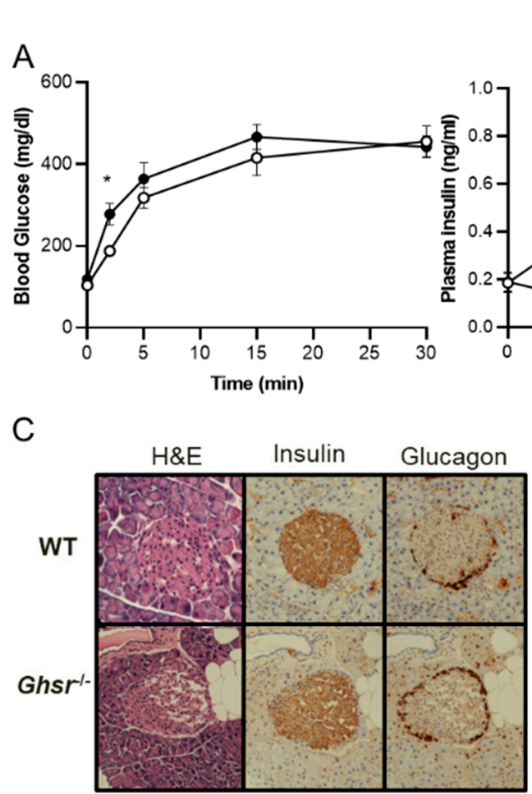
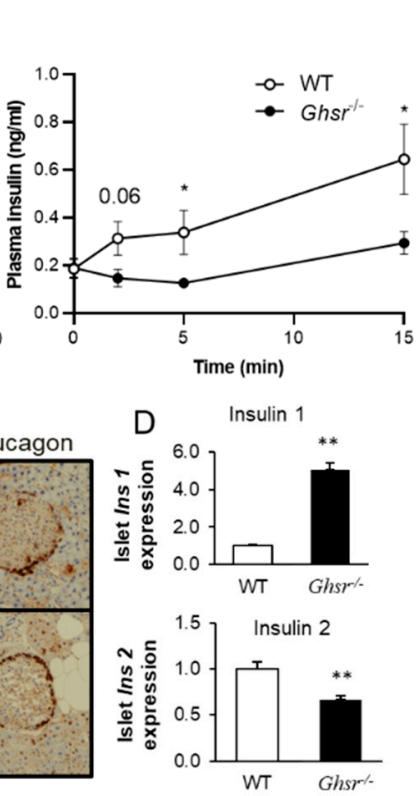

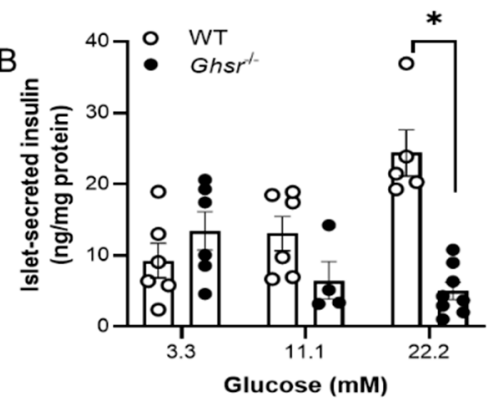

E

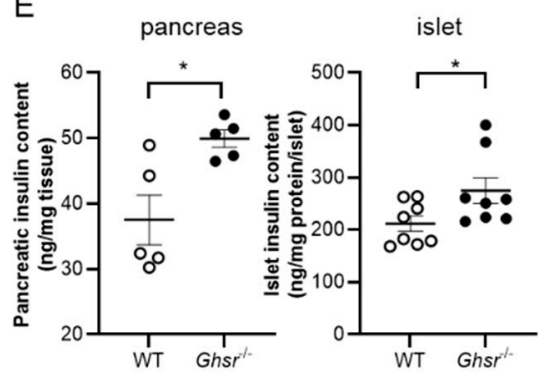

Figure 1. GHS-R ablation decreases glucose-stimulated insulin secretion (GSIS). (A) 4.5-month-old WT and $\mathrm{Ghsr}^{-/-}$mice were fasted overnight, and GSIS was performed in vivo, $n=5$. (B) Islets from 4-month-old WT and Ghsr ${ }^{-/-}$mice were treated with 3.3, 11.1 or $22.2 \mathrm{mM}$ glucose for $2 \mathrm{~h}$. Insulin content was measured and normalized to the total protein content of islets, $n=5-8$. (C) H\&E staining and immunostaining of insulin and glucagon of pancreatic sections from WT and Ghsr-/- mice. (D) Ins1 and Ins2 gene expression was measured from islets of 6.5 -month-old mice, $n=5$. (E) Insulin protein content of the whole pancreas ( 4 months, $n=5)$ and islet $(5.5 \mathrm{~m}, n=8)$ was measured and normalized by total protein content. ${ }^{*} p<0.05,{ }^{* *} p<0.001$, WT vs. Ghsr ${ }^{-/-}$. 


\subsection{Ghsr-/- Islets Exhibit Lower ATP/ADP Ratio}

To elucidate the mechanism underpinning Ghsr-deficiency-induced GSIS impairment, we investigated all the key steps of the GSIS signaling cascade as outlined below [59]. Glucose stimulation is known to induce the translocation of glucose transporter GLUT2 to the cell membrane, where it promotes the uptake of glucose molecules into the cytosol. The glucose is then hydrolyzed to generate ATP in the mitochondria. The increase of ATP leads to the closure of ATP-sensitive $\mathrm{K}+$ ATP channels in the cell membrane, which leads to depolarization of the membrane. This change in membrane voltage leads to the opening of voltage-sensitive $\mathrm{Ca} 2+$ channels and an influx of $\mathrm{Ca} 2+$ ions into the cytosol, which ultimately results in the exocytosis of the insulin granules [59]. To determine if GHS-R affects the membrane depolarization step, we treated the islets with $\mathrm{KCl}$, which is known to directly depolarize the membrane [60,61]. As detailed in Figure 2A, the insulin secreted from both WT and Ghsr ${ }^{-/-}$islets were similar after the KCl treatment, which suggests that Ghsr ablation likely impairs the upstream membrane depolarization step of the insulin secretion signaling cascade. Altered mitochondrial function is known to impair GSIS [62]. The DNA content in mitochondria was similar between the islets of the WT and $G h s r^{-/-}$mice (Figure 2B). To test mitochondrial function, we further investigated the $\mathrm{ATP} / \mathrm{ADP}$ ratio in islets of WT and $\mathrm{Ghsr}^{-/-}$mice. As shown in Figure 2C, the ATP/ADP ratio in WT islets was increased in $22.2 \mathrm{mM}$ glucose treatment compared to that of $3.3 \mathrm{mM}$ glucose treatment; the ATP/ADP ratio in $\mathrm{Ghsr}^{-/-}$islets was comparable under both 3.3 and $22.2 \mathrm{mM}$ glucose concentrations. Importantly, the ATP/ADP ratio in Ghsr-/- islets was significantly decreased at both 3.3 and $22.2 \mathrm{mM}$ glucose concentrations compared to WT islets (Figure 2C). These data indicate that Ghsr deletion does not impact the number of mitochondria but does impair the function of mitochondria.
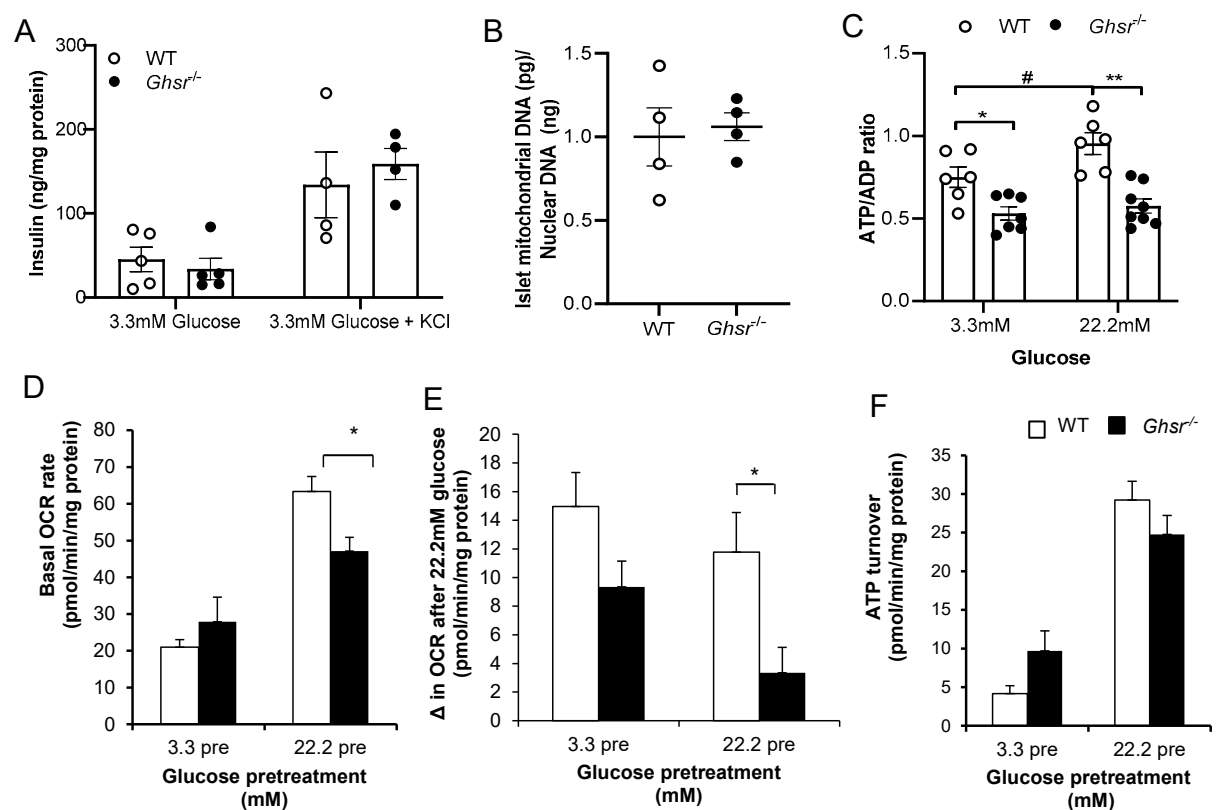

Figure 2. Ghsr /- islets have a lower ATP/ADP ratio. (A) Islets from WT and Ghsr ${ }^{-/-}$mice were treated with $3.3 \mathrm{mM}$ glucose in the presence or absence of $30 \mathrm{mM} \mathrm{KCl}$, and insulin was measured after $2 \mathrm{~h}$. Insulin was normalized to total protein content in islets, $n=4-5$. (B) Ratio of mitochondrial DNA to nuclear DNA content in islets. $n=4$. (C) 15 Islets/well from WT and Ghsr ${ }^{-/}$mice were treated with 3.3 or $22.2 \mathrm{mM}$ glucose for $2 \mathrm{~h}$, and then the ATP/ADP ratio was measured, $n=6-8$. (D) OCR was assessed in islets of WT and Ghsr ${ }^{-/}$mice. Islets of WT and $\mathrm{Ghsr}^{-/-}$mice were pretreated with 3.3 or $22.2 \mathrm{mM}$ glucose for $2 \mathrm{~h}$, and then the basal OCR rate was measured. (E) Change in OCR from baseline after $22.2 \mathrm{mM}$ glucose treatment. (F) ATP turnover, $n=3-5 .{ }^{*} p<0.05$, WT vs. Ghsr ${ }^{-/-}$; ** $p<0.001$, WT vs. Ghsr ${ }^{-/-}$; \# $p<0.05,3.3 \mathrm{mM}$ glucose vs. $22.2 \mathrm{mM}$ glucose (WT). 
To determine why mitochondrial function was altered, we further assessed the OCR of islets pretreated with either low glucose $(3.3 \mathrm{mM})$ or high glucose $(22.2 \mathrm{mM})$. As expected, islets treated with low glucose had a much lower basal OCR compared to islets treated with high glucose. The basal OCR of the Ghsr-/- islets treated with high glucose for $2 \mathrm{~h}$ was significantly lower than the WT islets treated with high glucose (Figure 2D). Upon further stimulation by glucose $(22.2 \mathrm{mM})$, we observed strikingly reduced OCR in $\mathrm{Ghsr}^{-/}$- islets pretreated with high glucose (Figure 2E). ATP turnover showed a trend of decrease in the $G h s r^{-/-}$islets pretreated with $22.2 \mathrm{mM}$ glucose but failed to reach statistical significance (Figure 2F). Together these findings suggest lower availability of substrates in the mitochondria of $\mathrm{Ghsr}^{-/}$- islets, which may contribute to reduced ATP generation.

\subsection{Glucose Uptake Is Reduced in Ghsr-Ablated Islets}

GLUT2 is the primary glucose transporter in rodent $\beta$-cells and plays a crucial role in glucose sensing and uptake [63]. The gene expression of Glut2 was significantly reduced in islets of $\mathrm{Ghsr}^{-/-}$mice (Figure 3A). G6P is known as the first substrate produced after glucose is transported into the $\beta$-cells [64]. Consistent with reduced Glut2 expression, we detected reduced G6P content in the pancreas of $\mathrm{Ghsr}^{-/-}$mice (Figure 3B). Our results indicate impaired GSIS in Ghsr $r^{-/}$islets is likely due to reduced uptake of glucose into the cytosol, which produces lower G6P levels, subsequently leading to a lower ATP/ADP ratio. The reduced ATP/ADP ratio then triggers insufficient membrane depolarization, which subsequently results in reduced GSIS (Figure 3C).

A
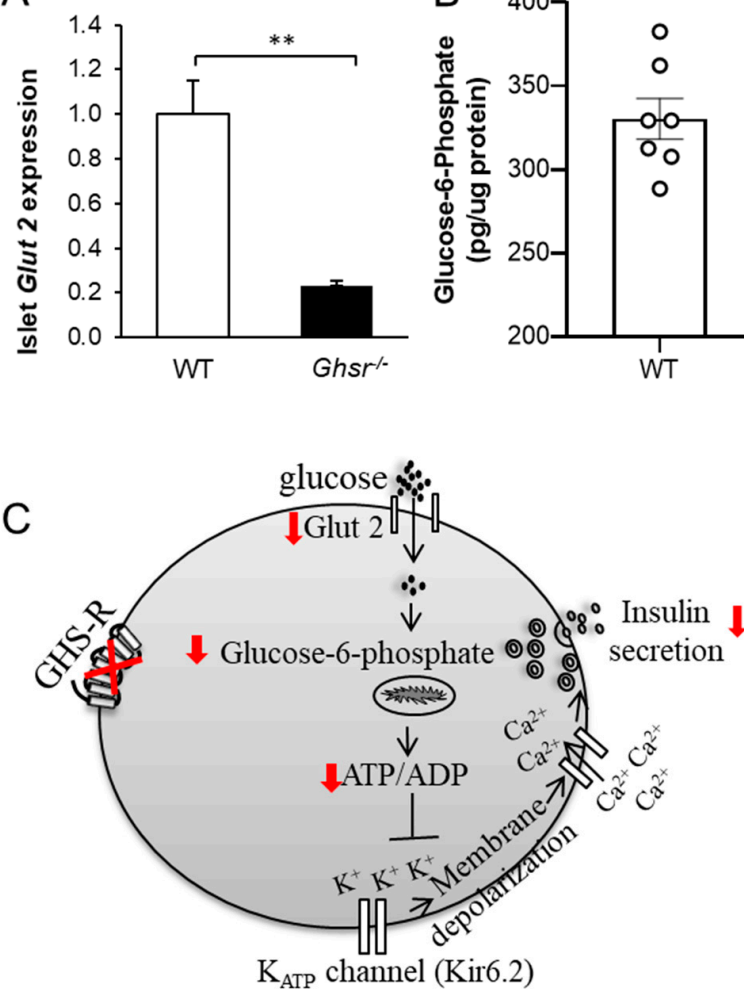

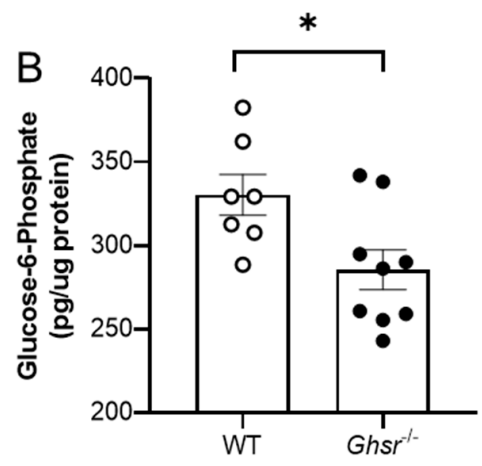

Figure 3. Glucose uptake is reduced in $\mathrm{Ghsr}^{-/-}$mice. (A) Glut2 gene expression was measured in islets of 6.5-month-old WT and Ghsr ${ }^{-/-}$mice, $n=5$. (B) G6P was measured from the pancreas of 4-month-old WT and Ghsr ${ }^{-/-}$mice, which were fasted overnight, injected with glucose and then sacrificed 60 min later, $n=7-9$. (C) Schematic diagram of impairments in GSIS pathway in Ghsr-ablated $\beta$-cells. Impaired Glut2 expression leads to the reduced formation of G6P, contributing to the lower generation of ATP, resulting in attenuated insulin secretion. ${ }^{*} p<0.05,{ }^{* *} p<0.001$, WT vs. Ghsr-/-. 


\subsection{Identification of Molecular Mediators Governing GHS-R Induced GSIS}

Components of the insulin signaling pathway have been previously suggested to regulate GSIS in pancreatic islets [35,39]. To investigate whether the insulin signaling pathway is altered in our system, the levels of gene expression of IR, IRS1, and IRS2 were measured. The expressions of $I R, I R S 1$, and IRS2 were significantly downregulated in $\mathrm{Ghsr}^{-/-}$islets mice compared to WT islets (Figure 4A). Next, we activated the insulin signaling pathway by injecting the mice with insulin and measured the phosphorylation of Akt. Under basal conditions (saline treatment), the phosphorylation of Akt seemed to be less in the pancreas of $\mathrm{Ghsr}^{-/-}$mice compared to WT. After insulin treatment, the phosphorylated Akt was dramatically increased in the WT pancreas as expected, and the increase in the $\mathrm{Ghsr}^{-/-}$pancreas was much less pronounced (Figure 4B).
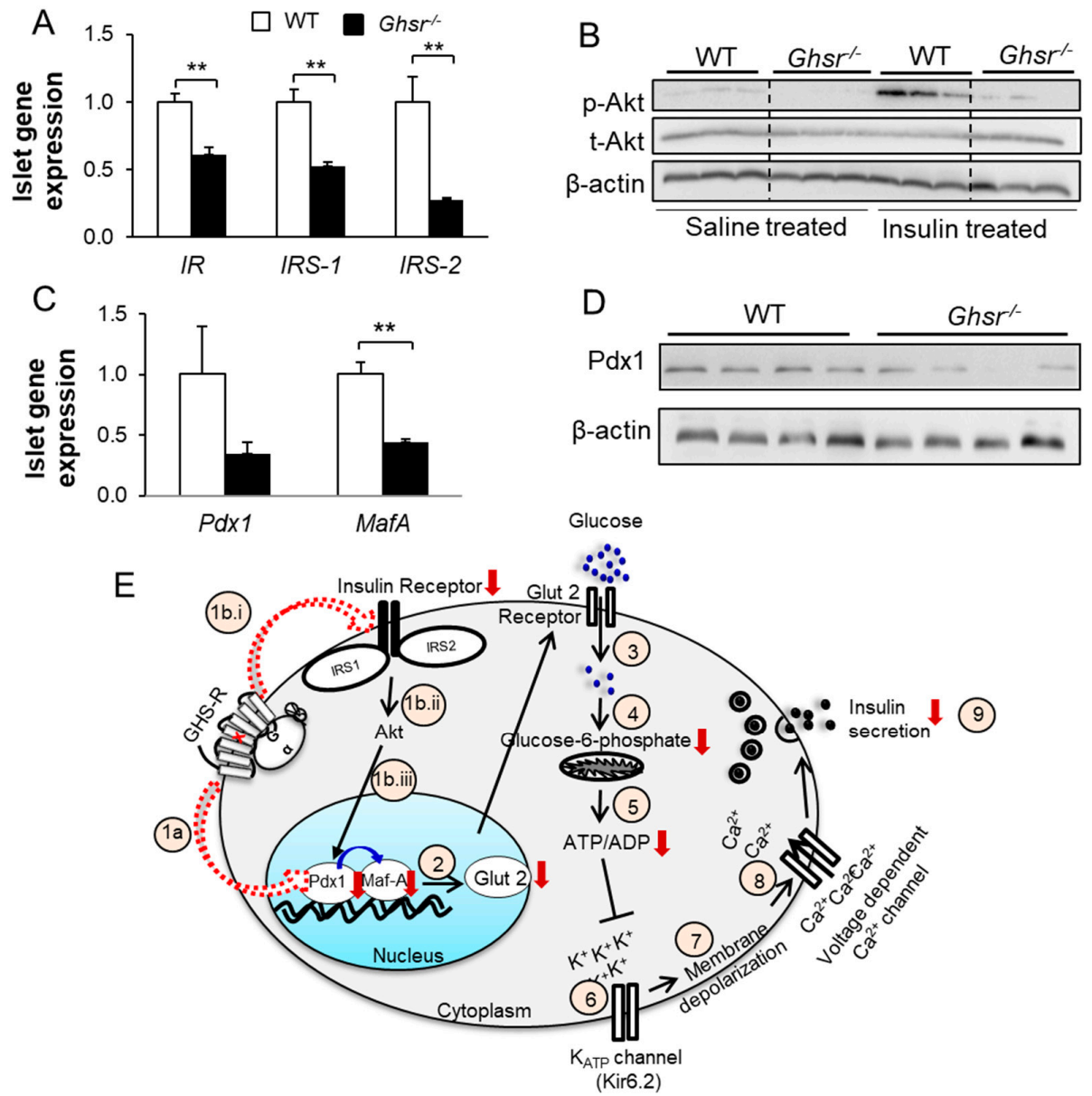

Figure 4. Genes of IR-IRS1/IRS2 pathway and transcription factor Pdx1 are downregulated in $\mathrm{Ghsr}^{-/-}$mice. (A) Gene expression of IR, IRS1, and IRS2 were measured in islets of 6.5-month-old mice, $n=5$. (B) Protein expression of $\mathrm{p}-\mathrm{AKT}$ and $\mathrm{t}-\mathrm{AKT}$ was measured in the pancreas from 12-14month-old WT and Ghsr ${ }^{-/-}$mice injected with saline or insulin. (C) Gene expression of transcription factors, $P d x 1$, and MafA were measured in islets of 6.5-month-old mice, $n=5$. (D) Protein expression of Pdx1 was measured in the pancreas of 5-month-old WT and Ghsr ${ }^{-/}$mice, $n=4$. (E) Schematic diagram illustrating that GHS-R regulates GSIS via the AKt-Pdx1 pathway. The numbers in the diagrams are denoted as below: (1) GHS-R ablation in $\beta$-cells downregulates Pdx1 and MafA either directly or indirectly reducing the expression of insulin signaling of IR, IRS1, IRS2, and Akt; (2) The downregulation of Pdx1 and MafA impairs Glut2 expression; (3) Reduced Glut2 expression leads to decreased glucose uptake; (4) Reduced generation of Glucose-6-phosphate leads to lower ATP/ADP ratio; (5) Reduced ATP / ADP ratio causes partial closing of ATP sensitive $\mathrm{K}_{\text {ATP }}$ channels (6), which leads to insufficient membrane depolarization (7); This ultimately results in a reduced influx of $\mathrm{Ca}^{2+}$ ions (8) that suppresses insulin secretion (9). ${ }^{* *} p<0.001$, WT vs. Ghsr ${ }^{-/-}$. 
A recent report demonstrated that the knockdown of IR in pancreatic $\beta$-cells contributes to reduced GSIS by downregulating the Pdx1-GLUT2 pathway [65]. Next, we set to determine if the downregulation of the IR-IRS1/IRS2-PI3K/Akt signaling pathway observed in $\mathrm{Ghsr}^{-/-}$islets is linked to reduced expression of Pdx1. Pdx1 and MafA are important transcription regulators in $\beta$-cells that are well known to regulate the expression of GLUT2 [66-69]. We observed lower expression of both $P d x 1$ and MafA in Ghsr-/- islets, though the difference in $P d x 1$ expression was not significant (Figure $4 C$ ). Consistently, the protein expression of Pdx1 was attenuated in the pancreas of $\mathrm{Ghsr}^{-/-}$mice compared to WT mice (Figure 4D). Overall, GHS-R ablation in $\beta$-cells downregulates Pdx1 and MafA, and suppresses the expression of key components of the IR-IRS1/IRS2-Akt pathway. It is possible that the downregulation of Pdx1 impairs Glut2 expression to reduce glucose uptake, which in turn suppresses G6P generation. Reduced G6P leads to a reduced ATP/ADP ratio, which then causes partial closure of $\mathrm{K}_{\mathrm{ATP}}$ channels and insufficient membrane depolarization, subsequently resulting in the reduced influx of $\mathrm{Ca}^{2+}$ ions and attenuated GSIS (Figure 4E).

\section{Discussion}

This is a comprehensive analysis of the GHS-R signaling on GSIS in Ghsr-/- mice and islets. Our findings suggest that GHS-R regulates GSIS via the Akt-Pdx1-GLUT2 pathway. We demonstrated that there is downregulation of GSIS in young Ghsr ${ }^{-/}$mice and in isolated pancreatic islets. Our data showed that the downregulation of insulin secretion is likely due to reduced glucose transport into islets, supported by reduced Glut2 expression and decreased G6P levels, which results in low ATP generation. Due to the reduced $\mathrm{ATP} / \mathrm{ADP}$ ratio, the downstream depolarization of the membrane via $\mathrm{K}^{+}$ATP channels and subsequent $\mathrm{Ca}^{2+}$ influx is abrogated, leading to decreased insulin secretion. The reduced Glut2 expression observed in $G h s r^{-/-}$islets could be attributed to the reduced expression of Pdx1 in these mice. Interestingly, we also detected lower gene expression of key insulin signaling genes such as IR, IRS1 and IRS2, as well as lower expression of phosphorylated Akt. Moreover, the insulin-stimulated phosphorylation of Akt was reduced in the pancreas of $\mathrm{Ghsr}^{-/-}$mice, further supporting the involvement of insulin signaling. Together, these results suggest that GHS-R regulates glucose-induced insulin release by regulating the glucose uptake via the Akt-Pdx1-GLUT2 pathway, supporting the existence of a crosstalk between the GHS-R and the insulin signaling pathway in the pancreatic islets.

In the pancreas, GHS-R mediates ghrelin's effects on insulin, glucagon, and somatostatin secretion [20-22]. Previously, we have extensively studied GHS-R null mouse models and demonstrated that young $\mathrm{Ghsr}^{-/-}$mice had similar body weight, body composition, food intake, and energy expenditure as control mice [53]. We also reported that ghrelin -GHS-R signaling plays an important role in regulating glucose homeostasis [44,70,71]. Our $\mathrm{Ghsr}^{-/-}$mice exhibited reduced glucose and insulin after overnight fasting [55], similar to the observation of Zigman et al. in their Ghsr-null mice [72]. In the present study, we found reduced GSIS in Ghsr-ablated islets and reduced first-phase insulin secretion in the $\mathrm{Ghsr}^{-/-}$mice compared to WT controls, consistent with our report of Ghsr- and leptindeleted $G h s r^{-/-}: o b / o b$ mice [28]. In our $\beta$-cell-specific GHS-R-deleted mouse model, where Ghs $r$ was deleted only in $\beta$-cells, the first-phase insulin secretion was reduced in vivo and ex vivo accompanied with improved insulin sensitivity, but no changes in body weight, body composition, food intake, or energy expenditure [73]. Together, all our data are in support of $\beta$-cell GHS-R as an important regulator of GSIS. However, our results differ from the study by Gray et al., where they reported similar GSIS in Ghsr-null mice and their islets [74]. We used 4.5-6.5 month-old mice/islets, Gray et al. used 2-2.5 month-old mice and 2-3-month-old islets. Mice undergo dramatic developmental changes between 2 and 6 months; the age difference may explain the discretionary of the data.

The morphology of Ghsr-/- islets appeared similar to WT islets, indicating that reduced GSIS is likely caused by GHS-R associated functional changes, not structural changes. In $\mathrm{Ghsr}^{-/-}$islets, the Insulin 1 gene was increased, whereas the Insulin 2 was 
significantly decreased (Figure 1). This increase of Ins1 could be a compensatory response to the downregulation of Ins2 in Ghsr-null islets. This is consistent with previous observation in Ins2-knockout islets that exhibit elevated Insulin 1 expression [75]. Similar differential expression of Insulin 1 and Insulin 2 have also been reported in $\beta$-cells under glucosestimulated conditions, with increased Insulin 1 expression and no change in Insulin 2 expression [76]. Notably, the insulin content in the whole pancreas and isolated islets was increased in the Ghsr ${ }^{-/}$mice, which could be a consequence of increased Insulin 1 expression and reduced secretion of insulin, further reserving the pool of insulin in the cytosol. These results indicate that $G h s r^{-/-}$islets have no inherent defect in their islet structure and overall total insulin production, but have the functional impairment of diminished exocytosis of insulin under glucose stimulation.

Mitochondrial metabolism plays a pivotal role in regulating GSIS; mitochondrial coupling and oxygen consumption are impaired in diabetic islets [77]. It has been previously reported that the oxygen consumption rate of $\beta$-cells is increased after glucose stimulation, suggesting accelerated $\beta$-cell metabolism leads to increased insulin secretion [78]. Our analysis of mitochondrial function in $\mathrm{Ghsr}^{-/-}$mice showed that oxygen consumption was reduced in the islets after $2 \mathrm{~h}$ of exposure to hyperglycemic conditions (Figure 2D). The reduced OCR and $\beta$-cell metabolism observed in $22.2 \mathrm{mM}$ glucose-pretreated Ghsr-ablated islets could lead to the reduced GSIS observed in these mice (Figure 1). Upon further stimulation with $22.2 \mathrm{mM}$ glucose, the OCR change in $G h s r^{-/}$- islets pretreated with $3.3 \mathrm{mM}$ glucose was more than the islets pretreated with $22.2 \mathrm{mM}$ glucose (Figure 2E). This is consistent with a previous study that hyperglycemia is associated with reduced mitochondrial metabolism in $\beta$-cells [77]. Mitochondrial metabolism has significant functional consequences, downstream in the GSIS pathway, as reduced ATP impairs membrane depolarization, calcium influx, and insulin exocytosis. Consequently, treatment of the Ghsr ${ }^{-/-}$ islets with a classical depolarizing agent, $\mathrm{KCl}$, sufficiently depolarized the membrane to restore insulin secretion to the levels of control mice.

Human $\beta$-cells express three different glucose transporters, GLUT1, GLUT2, and GLUT3 [79], while GLUT2 is the primary glucose transporter in rodent $\beta$-cells [63]. The loss of Glut2 expression in humans has been associated with impaired GSIS and the loss of firstphase insulin secretion in mice [80]. In the present study, Glut2 gene expression was reduced in Ghsr-ablated islets. Consequently, glucose uptake in $\beta$-cells was likely attenuated, which resulted in lower phosphorylation of glucose and reduced G6P in Ghsr-/- mice (Figure 3). Pdx1 is a key transcription regulator of $\beta$-cells, which is known to regulate expression by binding to the transcription promoter region of Glut2 [66,67], Insulin [66], and MafA [81]. Partial downregulation of Pdx1 expression is associated with $\beta$-cell dysfunction and $\beta$-cell death in rodents [82]. The lower Glut2 expression that we observed in Ghsr-/mice could be a consequence of downregulated $\operatorname{Pdx} 1$ expression in these mice, which is consistent with previous reports that reduced expression of $\mathrm{Pdx} 1$ results in the suppression of Glut2 $[67,83]$. MafA is a $\beta$-cell specific transcriptional factor that has been shown to induce the expression of Glut2 [68,69], Insulin [84,85], and $P d x 1[68,86]$. Interestingly, we observed a significant downregulation of MafA expression in the pancreatic islets of $\mathrm{Ghsr}^{-/-}$mice, which could be a result of $\mathrm{Pdx} 1$ downregulation in these mice. Our findings suggest that the downregulation of $\mathrm{Pdx} 1$ and MafA in Ghsr ${ }^{-/}-\beta$-cells possibly contributes to reduced Glut 2 expression, which eventually leads to the attenuation of glucose-stimulated insulin secretion.

Traditionally, insulin signaling and insulin secretion in the $\beta$-cells have been thought to be distinctive independent pathways. However, recent research has demonstrated that insulin can stimulate GSIS in humans [30] and rodents [31]. $\beta$-cell specific insulin receptor knockout $(\beta I R K O)$ mice exhibit loss of first-phase insulin secretion in response to glucose [35]. Low levels of IR and IRS2 have been reported in islets of diabetic humans [87], whereas IRS2 overexpression reduces the incidence of diabetes in non-obese diabetic mice [88]. Furthermore, insulin treatment of islets increases the nuclear translocation of Pdx1 [89], and IR isoform A improves glucose uptake by its association with Glut1/2 
in $\beta$-cells [90]. A recent report demonstrated that the knockdown of IR in pancreatic $\beta$ cells (INS-1) contributes to reduced GSIS mediated by downregulating the Pdx1-GLUT2 pathway [65]. It is possible that the attenuation of the Pdx1-GLUT2 pathway is a direct consequence of reduced insulin signaling in the $\beta$-cells of $\mathrm{Ghs}^{-/-}$mice. The activation of GHS-R has been shown to modulate IRS1-associated PI3K/Akt signaling in various cell types in vitro. In 3T3-L1 preadipocytes it has been reported that ghrelin via GHS$\mathrm{R}$ activates the IRS1-PI3K-Akt signaling pathway to induce proliferation and insulinstimulated glucose uptake $[45,46]$. In hepatoma cells, GHS-R activation ameliorates IRS1associated PI3K activity and suppresses Akt activity [47]. Here we are investigating whether GHS-R crosstalk with the IR-IRS1/IRS2-Akt pathway in the pancreatic $\beta$-cells. Activation of the insulin receptor upon ligand binding triggers a series of phosphorylation events, including phosphorylation of IRS1 and IRS2. The IRS proteins then activate the PI3K-Akt pathway, where Akt is phosphorylated [91]. Consistently, we observed an increase in insulin-induced Akt phosphorylation in the pancreas of WT mice, whereas Akt phosphorylation was reduced in the pancreas of $\mathrm{Ghsr}^{-/-}$mice (Figure 4). The evidence of reduced gene expression and signaling of IR-IRS1/IRS2-Akt pathway in the pancreas of $\mathrm{Ghsr}^{-/-}$mice suggests crosstalk between GHS-R and insulin signaling in the pancreas.

However, our data differ from some previous reports that showed increased insulin secretion with GHS-R antagonist treatment [20] and Ghsr-knockin mice [25]. The discrepancies could be due to differences in the model systems and/or experimental conditions to study glucose-induced insulin secretion. In our study, islets were allowed to recover from the collagenase shock from islet isolation by incubating them overnight in RPMI1640, whereas Kurashina et al. used fresh islets for their study [25,92]. Fresh islets could be under acute stress conditions due to collagenase treatment and other purification steps. Acute and chronic stress have been previously shown to increase insulin secretion in isolated islets $[93,94]$. Further, we used 4.5-6.5-month-old mature adult mice, whereas others have used 2-2.5-month-old mice/rats, which are still undergoing developmental changes [20,25].

Our study also has several limitations. First, in our current study, we cannot eliminate the potential involvement of other factors and indirect effects of ghrelin on $\beta$-cells, that could well contribute to the GSIS phenotype. A) GHS-R1a is known to have a very high constitutive activity and can signal at $50 \%$ of its maximum capacity even in the absence of ghrelin [95]. B) Zigman et al. demonstrated that the blocking of GHS-R by the endogenous ligand LEAP2 or synthetic ligand [D-Lys3]-GHRP-6 increases pancreatic plasma polypeptide (PP) in both fed and fasted states [18]. PP is a well-known inhibitor of insulin secretion [96,97]. It could be informative to investigate the concentrations of PP in our $\mathrm{Ghsr}^{-/-}$mice in the future. C) Recent studies using transcriptome profiling have demonstrated the GHS-R is highly expressed on somatostatin (SST) secreting $\delta$-cells $[14,22]$. Ghrelin can stimulate SST release in isolated pancreatic islets, perfused pancreas, and healthy humans, thus ghrelin-induced SST can inhibit insulin secretion via SST receptors in $\beta$-cells $[14,22,98-101]$. Recently, ghrelin-induced SST stimulation was suggested to be mediated by GHS-R1a activation in $\delta$-cells with the assistance of a GPCR accessory protein (Melanocortin Receptor Accessory Protein 2, MRAP2) [102]. We cannot eliminate the possibility of GHS-R1a independent ghrelin-mediated somatostatin release affecting GSIS in our studies. Ghrelin has been speculated to have GHS-R independent effects in other peripheral tissues [53,103-105]. It is possible that in our Ghsr ${ }^{-/-}$mouse model, ghrelin is mediating its inhibitory effect on GSIS via yet unknown GPCRs in pancreatic islets. D) Other peptides, such as urocortin 3 , which is highly expressed in $\beta$-cells, have been shown to inhibit somatostatin-mediated insulin secretion [106]. In the future, we may assess the urocortin 3 levels in our $\mathrm{Ghsr}^{-/-}$mice. Second, the putative signaling regulators in our study need to be further verified. Our studies suggest the existence of a crosstalk between GHS-R and IR-IRS1/IRS2-PI3K/Akt signaling in pancreatic islets that contributes to attenuated GSIS. Though we see reduced gene expression of insulin signaling components in $\mathrm{Ghsr}^{-/-}$islets, it is difficult to ascertain if it is a direct/causal effect of Ghsr on insulin signaling in $\beta$-cells. Further studies are needed to confirm the crosstalk 
between GHS-R and insulin signaling pathway, and verify if insulin signaling directly downregulates Pdx1 and contribute to GSIS. A very exciting recent report showed that ghrelin cell-selective insulin receptor-KO (GhIRKO) mice have reduced plasma insulin [107]; it would be interesting to investigate the insulin signaling in the $\beta$-cells of this mouse model. Third, we measured Glut 2 gene expression and glucose-metabolic intermediate G6P to assess glucose uptake into the cells. In the future, we should perform western blot or IHC to measure Glut 2 protein levels and provide more direct evidence of glucose imports in the $\beta$-cells.

Lastly, insulin resistance and impairment of GSIS in $\beta$-cells are hallmark features of diabetes. Our old $\mathrm{Ghsr}^{-/-}$mice are protected from age-associated insulin resistance [27]. Here, we demonstrate that at a young age, these Ghsr-/- mice exhibit reduced expression of insulin-signaling genes, lower GSIS, and high insulin sensitivity. It is possible that reduced GSIS and high insulin sensitivity at young age protect the Ghsr ${ }^{-/-}$mice from developing insulin resistance and T2D in aging [27].

In conclusion, our findings highlight that GHS-R is an important regulator of glucosestimulated insulin secretion both in vivo and ex vivo, and suggest the existence of a crosstalk between GHS-R and insulin-signaling pathways in pancreatic islets. GHS-R likely regulates GSIS via the Akt-Pdx1-GLUT2 pathway in pancreatic $\beta$-cells; in-depth studies are warranted to validate the signaling pathway.

Author Contributions: Conceptualization, G.P. and Y.S.; methodology, validation, formal analysis, G.P., J.H.L., H.W., C.-S.W., T.D., L.L. and S.L.S.; writing original draft, G.P., J.H.L., C.-S.W. and Y.S.; reviewing and editing, L.L., B.H.G., A.S.R., A.B., S.L.S. and S.G.; supervision, Y.S.; funding acquisition, Y.S., G.P. and S.G. All authors have read and agreed to the published version of the manuscript.

Funding: This research was funded by the American Diabetes Association grant \#1-15-BS-177, NIH 1R01DK118334, and AG064869 (YS). This work was also supported in part by the USDA National Institute of Food and Agriculture Hatch project 1010840 (YS), Burroughs Wellcome Fund training fellowship (BWF Grant No.1008200) of Houston Laboratory and Population Science Training Program in Gene-Environment Interaction (GP), and DK120968 (SG).

Institutional Review Board Statement: The study was conducted according to the guidelines of the Declaration of Helsinki and approved by the Institutional Review Board of the Baylor College of Medicine (protocol code AN2770 and approved on 20 May 2014).

Conflicts of Interest: The authors declare no conflict of interest.

\section{References}

1. Date, Y.; Kojima, M.; Hosoda, H.; Sawaguchi, A.; Mondal, M.S.; Suganuma, T.; Matsukura, S.; Kangawa, K.; Nakazato, M. Ghrelin, a Novel Growth Hormone-Releasing Acylated Peptide, Is Synthesized in a Distinct Endocrine Cell Type in the Gastrointestinal Tracts of Rats and Humans. Endocrinology 2000, 141, 4255-4261. [CrossRef] [PubMed]

2. Kojima, M.; Hosoda, H.; Date, Y.; Nakazato, M.; Matsuo, H.; Kangawa, K. Ghrelin is a growth-hormone-releasing acylated peptide from stomach. Nature 1999, 402, 656-660. [CrossRef] [PubMed]

3. Prado, C.L.; Pugh-Bernard, A.E.; Elghazi, L.; Sosa-Pineda, B.; Sussel, L. Ghrelin cells replace insulin-producing cells in two mouse models of pancreas development. Proc. Natl. Acad. Sci. USA 2004, 101, 2924-2929. [CrossRef] [PubMed]

4. Granata, R.; Settanni, F.; Gallo, D.; Trovato, L.; Biancone, L.; Cantaluppi, V.; Nano, R.; Annunziata, M.; Campiglia, P.; Arnoletti, E.; et al. Obestatin Promotes Survival of Pancreatic Beta-Cells and Human Islets and Induces Expression of Genes Involved in the Regulation of -Cell Mass and Function. Diabetes 2007, 57, 967-979. [CrossRef]

5. Volante, M.; Allìa, E.; Gugliotta, P.; Funaro, A.; Broglio, F.; Deghenghi, R.; Muccioli, G.; Ghigo, E.; Papotti, M. Expression of Ghrelin and of the GH Secretagogue Receptor by Pancreatic Islet Cells and Related Endocrine Tumors. J. Clin. Endocrinol. Metab. 2002, 87, 1300-1308. [CrossRef]

6. Wierup, N.; Yang, S.; McEvilly, R.J.; Mulder, H.; Sundler, F. Ghrelin Is Expressed in a Novel Endocrine Cell Type in Developing Rat Islets and Inhibits Insulin Secretion from INS-1 (832/13) Cells. J. Histochem. Cytochem. 2004, 52, 301-310. [CrossRef]

7. Date, Y.; Nakazato, M.; Hashiguchi, S.; Dezaki, K.; Mondal, M.S.; Hosoda, H.; Kojima, M.; Kangawa, K.; Arima, T.; Matsuo, H.; et al. Ghrelin Is Present in Pancreatic $\alpha$-Cells of Humans and Rats and Stimulates Insulin Secretion. Diabetes 2002, 51, 124-129. [CrossRef]

8. Hosoda, H.; Kangawa, K. The autonomic nervous system regulates gastric ghrelin secretion in rats. Regul. Pept. 2008, 146, 12-18. [CrossRef] 
9. Dezaki, K.; Hosoda, H.; Kakei, M.; Hashiguchi, S.; Watanabe, M.; Kangawa, K.; Yada, T. Endogenous ghrelin in pancreatic islets restricts insulin release by attenuating $\mathrm{Ca}^{2+}$ signaling in beta-cells: Implication in the glycemic control in rodents. Diabetes 2004, 53, 3142-3151. [CrossRef]

10. Reimer, M.K.; Pacini, G.; Ahrén, B. Dose-Dependent Inhibition by Ghrelin of Insulin Secretion in the Mouse. Endocrinology 2003, 144, 916-921. [CrossRef]

11. Röder, P.V.; Wu, B.; Liu, Y.; Han, W. Pancreatic regulation of glucose homeostasis. Exp. Mol. Med. 2016, 48, e219. [CrossRef]

12. Komatsu, M.; Takei, M.; Ishii, H.; Sato, Y. Glucose-stimulated insulin secretion: A newer perspective. J. Diabetes Investig. 2013, 4, 511-516. [CrossRef]

13. Sun, Y.; Wang, P.; Zheng, H.; Smith, R.G. Ghrelin stimulation of growth hormone release and appetite is mediated through the growth hormone secretagogue receptor. Proc. Natl. Acad. Sci. USA 2004, 101, 4679-4684. [CrossRef]

14. DiGruccio, M.R.; Mawla, A.M.; Donaldson, C.J.; Noguchi, G.M.; Vaughan, J.; Cowing-Zitron, C.; van der Meulen, T.; Huising, M.O. Comprehensive alpha, beta and delta cell transcriptomes reveal that ghrelin selectively activates delta cells and promotes somatostatin release from pancreatic islets. Mol. Metab. 2016, 5, 449-458. [CrossRef]

15. Gnanapavan, S.; Kola, B.; Bustin, S.A.; Morris, D.G.; McGee, P.; Fairclough, P.; Bhattacharya, S.; Carpenter, R.; Grossman, A.B.; Korbonits, M. The tissue distribution of the mRNA of ghrelin and subtypes of its receptor, GHS-R, in humans. J. Clin. Endocrinol. Metab. 2002, 87, 2988. [CrossRef]

16. Granata, R.; Baragli, A.; Settanni, F.; Scarlatti, F.; Ghigo, E. Unraveling the role of the ghrelin gene peptides in the endocrine pancreas. J. Mol. Endocrinol. 2010, 45, 107-118. [CrossRef]

17. Anderwald-Stadler, M.; Krebs, M.; Promintzer, M.; Mandl, M.; Bischof, M.G.; Nowotny, P.; Kästenbauer, T.; Luger, A.; Prager, R.; Anderwald, C. Plasma obestatin is lower at fasting and not suppressed by insulin in insulin-resistant humans. Am. J. Physiol. Metab. 2007, 293, E1393-E1398. [CrossRef]

18. Gupta, D.; Dowsett, G.K.C.; Mani, B.K.; Shankar, K.; Osborne-Lawrence, S.; Metzger, N.P.; Lam, B.Y.H.; Yeo, G.S.H.; Zigman, J.M. High Coexpression of the Ghrelin and LEAP2 Receptor GHSR With Pancreatic Polypeptide in Mouse and Human Islets. Endocrinology 2021, 162, bqab148. [CrossRef]

19. Yu, X.-X.; Qiu, W.-L.; Yang, L.; Wang, Y.-C.; He, M.-Y.; Wang, D.; Zhang, Y.; Li, L.-C.; Zhang, J.; Wang, Y.; et al. Sequential progenitor states mark the generation of pancreatic endocrine lineages in mice and humans. Cell Res. 2021, 31, 886-903. [CrossRef]

20. Dezaki, K.; Sone, H.; Koizumi, M.; Nakata, M.; Kakei, M.; Nagai, H.; Hosoda, H.; Kangawa, K.; Yada, T. Blockade of Pancreatic Islet-Derived Ghrelin Enhances Insulin Secretion to Prevent High-Fat Diet-Induced Glucose Intolerance. Diabetes 2006, 55, 3486-3493. [CrossRef]

21. Chuang, J.-C.; Sakata, I.; Kohno, D.; Perello, M.; Osborne-Lawrence, S.; Repa, J.J.; Zigman, J.M. Ghrelin Directly Stimulates Glucagon Secretion from Pancreatic $\alpha$-Cells. Mol. Endocrinol. 2011, 25, 1600-1611. [CrossRef] [PubMed]

22. Adriaenssens, A.E.; Svendsen, B.Y.; Lam, B.; Yeo, G.S.H.; Holst, J.J.; Reimann, F.; Gribble, F.M. Transcriptomic profiling of pancreatic alpha, beta and delta cell populations identifies delta cells as a principal target for ghrelin in mouse islets. Diabetologia 2016, 59, 2156-2165. [CrossRef]

23. Dezaki, K.; Kakei, M.; Yada, T. Ghrelin uses Galpha $\mathrm{i}_{2}$ and activates voltage-dependent $\mathrm{K}^{+}$channels to attenuate glucose-induced $\mathrm{Ca}^{2+}$ signaling and insulin release in islet beta-cells: Novel signal transduction of ghrelin. Diabetes 2007, 56, 2319-2327. [CrossRef] [PubMed]

24. Park, S.; Jiang, H.; Zhang, H.; Smith, R.G. Modification of ghrelin receptor signaling by somatostatin receptor-5 regulates insulin release. Proc. Natl. Acad. Sci. USA 2012, 109, 19003-19008. [CrossRef] [PubMed]

25. Kurashina, T.; Dezaki, K.; Yoshida, M.; Rita, R.S.; Ito, K.; Taguchi, M.; Miura, R.; Tominaga, M.; Ishibashi, S.; Kakei, M.; et al. The $\beta$-cell GHSR and downstream cAMP/TRPM2 signaling account for insulinostatic and glycemic effects of ghrelin. Sci. Rep. 2015, 5, 14041. [CrossRef] [PubMed]

26. Sun, Y.; Asnicar, M.; Saha, P.K.; Chan, L.; Smith, R.G. Ablation of ghrelin improves the diabetic but not obese phenotype of ob/ob mice. Cell Metab. 2006, 3, 379-386. [CrossRef] [PubMed]

27. Lin, L.; Saha, P.K.; Ma, X.; Henshaw, I.O.; Shao, L.; Chang, B.H.J.; Buras, E.D.; Tong, Q.; Chan, L.; McGuinness, O.P.; et al. Ablation of ghrelin receptor reduces adiposity and improves insulin sensitivity during aging by regulating fat metabolism in white and brown adipose tissues. Aging Cell 2011, 10, 996-1010. [CrossRef] [PubMed]

28. Ma, X.; Lin, Y.; Lin, L.; Qin, G.; Pereira, F.A.; Haymond, M.W.; Butte, N.F.; Sun, Y. Ablation of ghrelin receptor in leptin-deficient $\mathrm{ob} / \mathrm{ob}$ mice has paradoxical effects on glucose homeostasis when compared with ablation of ghrelin in ob/ob mice. Am. J. Physiol. Endocrinol. Metab. 2012, 303, E422-E431. [CrossRef]

29. White, M.F.; Kahn, C.R. Insulin action at a molecular level-100 years of progress. Mol. Metab. 2021, 52, 101304. [CrossRef]

30. Aspinwall, C.A.; Lakey, J.R.T.; Kennedy, R.T. Insulin-stimulated Insulin Secretion in Single Pancreatic Beta Cells. J. Biol. Chem. 1999, 274, 6360-6365. [CrossRef]

31. Assmann, A.; Hinault, C.; Kulkarni, R.N. Growth factor control of pancreatic islet regeneration and function. Pediatr. Diabetes 2009, 10, 14-32. [CrossRef] [PubMed]

32. Bouche, C.; Lopez, X.; Fleischman, A.; Cypess, A.M.; O'Shea, S.; Stefanovski, D.; Bergman, R.N.; Rogatsky, E.; Stein, D.T.; Kahn, C.R.; et al. Insulin enhances glucose-stimulated insulin secretion in healthy humans. Proc. Natl. Acad. Sci. USA 2010, 107, 4770-4775. [CrossRef] [PubMed] 
33. Halperin, F.; Lopez, X.; Manning, R.; Kahn, C.R.; Kulkarni, R.N.; Goldfine, A.B. Insulin Augmentation of Glucose-Stimulated Insulin Secretion Is Impaired in Insulin-Resistant Humans. Diabetes 2012, 61, 301-309. [CrossRef] [PubMed]

34. Anderwald, C.; Tura, A.; Grassi, A.; Krebs, M.; Szendroedi, J.; Roden, M.; Bischof, M.G.; Luger, A.; Pacini, G. Insulin Infusion During Normoglycemia Modulates Insulin Secretion According to Whole-Body Insulin Sensitivity. Diabetes Care 2011, 34, 437-441. [CrossRef]

35. Kulkarni, R.N.; Brüning, J.C.; Winnay, J.N.; Postic, C.; Magnuson, M.; Kahn, C. Tissue-Specific Knockout of the Insulin Receptor in Pancreatic $\beta$ Cells Creates an Insulin Secretory Defect Similar to that in Type 2 Diabetes. Cell 1999, 96, 329-339. [CrossRef]

36. Kulkarni, R.N.; Winnay, J.N.; Daniels, M.; Brüning, J.C.; Flier, S.N.; Hanahan, D.; Kahn, C.R. Altered function of insulin receptor substrate-1-deficient mouse islets and cultured $\beta$-cell lines. J. Clin. Investig. 1999, 104, R69-R75. [CrossRef]

37. Withers, D.; Gutierrez, J.S.; Towery, H.; Burks, D.J.; Ren, J.-M.; Previs, S.; Zhang, Y.; Bernal, D.; Pons, S.; Shulman, G.; et al. Disruption of IRS-2 causes type 2 diabetes in mice. Nature 1998, 391, 900-904. [CrossRef]

38. Cho, H.; Mu, J.; Kim, J.K.; Thorvaldsen, J.L.; Chu, Q.; Crenshaw, E.B.; Kaestner, K.H.; Bartolomei, M.S.; Shulman, G.I.; Birnbaum, M.J. Insulin Resistance and a Diabetes Mellitus-Like Syndrome in Mice Lacking the Protein Kinase Akt2 (PKB $\beta$ ). Science 2001, 292, 1728-1731. [CrossRef]

39. Kaneko, K.; Ueki, K.; Takahashi, N.; Hashimoto, S.; Okamoto, M.; Awazawa, M.; Okazaki, Y.; Ohsugi, M.; Inabe, K.; Umehara, T.; et al. Class IA Phosphatidylinositol 3-Kinase in Pancreatic $\beta$ Cells Controls Insulin Secretion by Multiple Mechanisms. Cell Metab. 2010, 12, 619-632. [CrossRef]

40. Guillam, M.T.; Hummler, E.; Schaerer, E.; Yeh, J.I.; Birnbaum, M.J.; Beermann, F.; Schmidt, A.; Deriaz, N.; Thorens, B. Early diabetes and abnormal postnatal pancreatic islet development in mice lacking Glut-2. Nat. Genet. 1997, 17, 327-330. [CrossRef]

41. Poykko, S.M.; Kellokoski, E.; Horkko, S.; Kauma, H.; Kesaniemi, Y.A.; Ukkola, O. Low Plasma Ghrelin Is Associated With Insulin Resistance, Hypertension, and the Prevalence of Type 2 Diabetes. Diabetes 2003, 52, 2546-2553. [CrossRef] [PubMed]

42. Purnell, J.Q.; Weigle, D.S.; Breen, P.; Cummings, D.E. Ghrelin Levels Correlate with Insulin Levels, Insulin Resistance, and High-Density Lipoprotein Cholesterol, But Not with Gender, Menopausal Status, or Cortisol Levels in Humans. J. Clin. Endocrinol. Metab. 2003, 88, 5747-5752. [CrossRef] [PubMed]

43. Ikezaki, A.; Hosoda, H.; Ito, K.; Iwama, S.; Miura, N.; Matsuoka, H.; Kondo, C.; Kojima, M.; Kangawa, K.; Sugihara, S. Fasting Plasma Ghrelin Levels Are Negatively Correlated With Insulin Resistance and PAI-1, but Not With Leptin, in Obese Children and Adolescents. Diabetes 2002, 51, 3408-3411. [CrossRef] [PubMed]

44. Pradhan, G.; Samson, S.L.; Sun, Y. Ghrelin: Much more than a hunger hormone. Curr. Opin. Clin. Nutr. Metab. Care 2013, 16, 619-624. [CrossRef] [PubMed]

45. Kim, M.S.; Yoon, C.Y.; Jang, P.G.; Park, Y.J.; Shin, C.S.; Park, H.S.; Ryu, J.W.; Pak, Y.K.; Park, J.Y.; Lee, K.U.; et al. The Mitogenic and Antiapoptotic Actions of Ghrelin in 3T3-L1 Adipocytes. Mol. Endocrinol. 2004, 18, 2291-2301. [CrossRef]

46. Yin, Y.; Li, Y.; Zhang, W. The Growth Hormone Secretagogue Receptor: Its Intracellular Signaling and Regulation. Int. J. Mol. Sci. 2014, 15, 4837-4855. [CrossRef]

47. Murata, M.; Okimura, Y.; Iida, K.; Matsumoto, M.; Sowa, H.; Kaji, H.; Kojima, M.; Kangawa, K.; Chihara, K. Ghrelin Modulates the Downstream Molecules of Insulin Signaling in Hepatoma Cells. J. Biol. Chem. 2002, 277, 5667-5674. [CrossRef]

48. Yeung, E.; Zhang, C.; Mumford, S.; Ye, A.; Trevisan, M.; Chen, L.; Browne, R.W.; Wactawski-Wende, J.; Schisterman, E. Longitudinal Study of Insulin Resistance and Sex Hormones over the Menstrual Cycle: The BioCycle Study. J. Clin. Endocrinol. Metab. 2010, 95, 5435-5442. [CrossRef]

49. Li, D.-S.; Yuan, Y.-H.; Tu, H.-J.; Liang, Q.-L.; Dai, L.-J. A protocol for islet isolation from mouse pancreas. Nat. Protoc. 2009, 4, 1649-1652. [CrossRef]

50. Villarreal, D.; Pradhan, G.; Wu, C.S.; Allred, C.D.; Guo, S.; Sun, Y. A Simple High Efficiency Protocol for Pancreatic Islet Isolation from Mice. J. Vis. Exp. 2019, 150, e57048. [CrossRef]

51. Hohmeier, H.E.; Mulder, H.; Chen, G.; Henkel-Rieger, R.; Prentki, M.; Newgard, C.B. Isolation of INS-1-derived cell lines with robust ATP-sensitive $\mathrm{K}^{+}$channel-dependent and -independent glucose-stimulated insulin secretion. Diabetes 2000, 49, 424-430. [CrossRef] [PubMed]

52. Robertson, K.; Kopchick, J.J.; Liu, J.-L. Growth hormone receptor gene deficiency causes delayed insulin responsiveness in skeletal muscles without affecting compensatory islet cell overgrowth in obese mice. Am. J. Physiol. Metab. 2006, 291, E491-E498. [CrossRef] [PubMed]

53. Ma, X.; Lin, L.; Qin, G.; Lu, X.; Fiorotto, M.; Dixit, V.D.; Sun, Y. Ablations of Ghrelin and Ghrelin Receptor Exhibit Differential Metabolic Phenotypes and Thermogenic Capacity during Aging. PLoS ONE 2011, 6, e16391. [CrossRef] [PubMed]

54. Chomczynski, P.; Sacchi, N. Single-step method of RNA isolation by acid guanidinium thiocyanate-phenol-chloroform extraction. Anal. Biochem. 1987, 162, 156-159. [CrossRef]

55. Sun, Y.; Butte, N.F.; Garcia, J.M.; Smith, R.G. Characterization of Adult Ghrelin and Ghrelin Receptor Knockout Mice under Positive and Negative Energy Balance. Endocrinology 2007, 149, 843-850. [CrossRef]

56. Wentworth, B.M.; Schaefer, I.M.; Villa-Komaroff, L.; Chirgwin, J.M. Characterization of the two nonallelic genes encoding mouse preproinsulin. J. Mol. Evol. 1986, 23, 305-312. [CrossRef]

57. Shiao, M.-S.; Liao, B.-Y.; Long, M.; Yu, H.-T. Adaptive Evolution of the Insulin Two-Gene System in Mouse. Genet. 2008, 178, 1683-1691. [CrossRef] 
58. Li, L.; Gao, L.; Wang, K.; Ma, X.; Chang, X.; Shi, J.-H.; Zhang, Y.; Yin, K.; Liu, Z.; Shi, Y.; et al. Knockin of Cre Gene at Ins2 Locus Reveals No Cre Activity in Mouse Hypothalamic Neurons. Sci. Rep. 2016, 6, 20438. [CrossRef]

59. Jensen, M.V.; Joseph, J.W.; Ronnebaum, S.M.; Burgess, S.C.; Sherry, A.D.; Newgard, C.B. Metabolic cycling in control of glucosestimulated insulin secretion. Am. J. Physiol. Metab. 2008, 295, E1287-E1297. [CrossRef]

60. Zhu, L.; Almaça, J.; Dadi, P.K.; Hong, H.; Sakamoto, W.; Rossi, M.; Lee, R.; Vierra, N.C.; Lu, H.; Cui, Y.; et al. $\beta$-arrestin-2 is an essential regulator of pancreatic $\beta$-cell function under physiological and pathophysiological conditions. Nat. Commun. 2017, 8 , 14295. [CrossRef]

61. Brüning, D.; Reckers, K.; Drain, P.; Rustenbeck, I. Glucose but not $\mathrm{KCl}$ diminishes submembrane granule turnover in mouse beta-cells. J. Mol. Endocrinol. 2017, 59, 311-324. [CrossRef] [PubMed]

62. Lu, H.; Koshkin, V.; Allister, E.M.; Gyulkhandanyan, A.V.; Wheeler, M.B. Molecular and Metabolic Evidence for Mitochondrial Defects Associated with $\beta$-Cell Dysfunction in a Mouse Model of Type 2 Diabetes. Diabetes 2009, 59, 448-459. [CrossRef] [PubMed]

63. Thorens, B. GLUT2, glucose sensing and glucose homeostasis. Diabetologia 2014, 58, 221-232. [CrossRef] [PubMed]

64. Yu, L.; Chen, X.; Wang, L.; Chen, S. The sweet trap in tumors: Aerobic glycolysis and potential targets for therapy. Oncotarget 2016, 7, 38908-38926. [CrossRef] [PubMed]

65. Wang, J.; Gu, W.; Chen, C. Knocking down Insulin Receptor in Pancreatic Beta Cell lines with Lentiviral-Small Hairpin RNA Reduces Glucose-Stimulated Insulin Secretion via Decreasing the Gene Expression of Insulin, GLUT2 and Pdx1. Int. J. Mol. Sci. 2018, 19, 985. [CrossRef] [PubMed]

66. Watada, H.; Kajimoto, Y.; Miyagawa, J.-I.; Hanafusa, T.; Hamaguchi, K.; Matsuoka, T.-A.; Yamamoto, K.; Matsuzawa, Y.; Kawamori, R.; Yamasaki, Y. PDX-1 Induces Insulin and Glucokinase Gene Expressions in $\alpha$ TC1 Clone 6 Cells in the Presence of Betacellulin. Diabetes 1996, 45, 1826-1831. [CrossRef]

67. Wang, H.; Maechler, P.; Ritz-Laser, B.; Hagenfeldt, K.A.; Ishihara, H.; Philippe, J.; Wollheim, C.B. Pdx1 Level Defines Pancreatic Gene Expression Pattern and Cell Lineage Differentiation. J. Biol. Chem. 2001, 276, 25279-25286. [CrossRef]

68. Wang, H.; Brun, T.; Kataoka, K.; Sharma, A.J.; Wollheim, C.B. MAFA controls genes implicated in insulin biosynthesis and secretion. Diabetologia 2006, 50, 348-358. [CrossRef]

69. Matsuoka, T.-A.; Kaneto, H.; Stein, R.; Miyatsuka, T.; Kawamori, D.; Henderson, E.; Kojima, I.; Matsuhisa, M.; Hori, M.; Yamasaki, Y. MafA Regulates Expression of Genes Important to Islet $\beta$-Cell Function. Mol. Endocrinol. 2007, 21, 2764-2774. [CrossRef]

70. Pradhan, G.; Wu, C.S.; Lee, J.H.; Kanikarla, P.; Guo, S.; Yechoor, V.K.; Samson, S.L.; Sun, Y. Obestatin stimulates glucose-induced insulin secretion through ghrelin receptor GHS-R. Sci. Rep. 2017, 7, 979. [CrossRef]

71. Wu, C.-S.; Bongmba, O.Y.N.; Lee, J.H.; Tuchaai, E.; Zhou, Y.; Li, D.-P.; Xue, B.; Chen, Z.; Sun, Y. Ghrelin receptor in agouti-related peptide neurones regulates metabolic adaptation to calorie restriction. J. Neuroendocr. 2019, 31, e12763. [CrossRef] [PubMed]

72. Zigman, J.M.; Nakano, Y.; Coppari, R.; Balthasar, N.; Marcus, J.N.; Lee, C.E.; Jones, J.E.; Deysher, A.E.; Waxman, A.R.; White, R.D.; et al. Mice lacking ghrelin receptors resist the development of diet-induced obesity. J. Clin. Investig. 2005, 115, 3564-3572. [CrossRef] [PubMed]

73. Pradhan, G.; Wu, C.-S.; Villarreal, D.; Lee, J.; Han, H.; Gaharwar, A.; Tian, Y.; Fu, W.; Guo, S.; Smith, R.; et al. $\beta$ Cell GHS-R Regulates Insulin Secretion and Sensitivity. Int. J. Mol. Sci. 2021, 22, 3950. [CrossRef] [PubMed]

74. Gray, S.M.; Niu, J.; Zhang, A.; Svendsen, B.; Campbell, J.E.; D’Alessio, D.A.; Tong, J. Intraislet Ghrelin Signaling Does Not Regulate Insulin Secretion From Adult Mice. Diabetes 2019, 68, 1795-1805. [CrossRef] [PubMed]

75. Leroux, L.; Desbois, P.; Lamotte, L.; Duvillié, B.; Cordonnier, N.; Jackerott, M.; Jami, J.; Bucchini, D.; Joshi, R.L. Compensatory responses in mice carrying a null mutation for Ins1 or Ins2. Diabetes 2001, 50 (Suppl. 1), 150-153. [CrossRef]

76. Roderigo-Milne, H.; Hauge-Evans, A.C.; Persaud, S.; Jones, P. Differential expression of insulin genes 1 and 2 in MIN6 cells and pseudoislets. Biochem. Biophys. Res. Commun. 2002, 296, 589-595. [CrossRef]

77. Haythorne, E.; Rohm, M.; Van De Bunt, M.; Brereton, M.F.; Tarasov, A.I.; Blacker, T.S.; Sachse, G.; Dos Santos, M.S.; Exposito, R.T.; Davis, S.; et al. Diabetes causes marked inhibition of mitochondrial metabolism in pancreatic $\beta$-cells. Nat. Commun. 2019, 10, 2474. [CrossRef]

78. Wang, W.; Upshaw, L.; Strong, D.M.; Robertson, R.P.; Reems, J. Increased oxygen consumption rates in response to high glucose detected by a novel oxygen biosensor system in non-human primate and human islets. J. Endocrinol. 2005, 185, 445-455. [CrossRef]

79. McCulloch, L.J.; van de Bunt, M.; Braun, M.; Frayn, K.N.; Clark, A.; Gloyn, A.L. GLUT2 (SLC2A2) is not the principal glucose transporter in human pancreatic beta cells: Implications for understanding genetic association signals at this locus. Mol. Genet. Metab. 2011, 104, 648-653. [CrossRef]

80. Ohtsubo, K.; Takamatsu, S.; Minowa, M.T.; Yoshida, A.; Takeuchi, M.; Marth, J.D. Dietary and Genetic Control of Glucose Transporter 2 Glycosylation Promotes Insulin Secretion in Suppressing Diabetes. Cell 2005, 123, 1307-1321. [CrossRef]

81. Raum, J.C.; Gerrish, K.; Artner, I.; Henderson, E.; Guo, M.; Sussel, L.; Schisler, J.; Newgard, C.B.; Stein, R. FoxA2, Nkx2.2, and PDX-1 Regulate Islet $\beta$-Cell-Specific mafA Expression through Conserved Sequences Located between Base Pairs -8118 and -7750 Upstream from the Transcription Start Site. Mol. Cell. Biol. 2006, 26, 5735-5743. [CrossRef] [PubMed]

82. Weir, G.C.; Sharma, A.; Zangen, D.H.; Bonner-Weir, S. Transcription factor abnormalities as a cause of beta cell dysfunction in diabetes: A hypothesis. Acta Diabetol. 1997, 34, 177-184. [CrossRef]

83. Ahlgren, U.; Jonsson, J.; Jonsson, L.; Simu, K.; Edlund, H. $\beta$-Cell-specific inactivation of the mouseIpf1/Pdx1 gene results in loss of the $\beta$-cell phenotype and maturity onset diabetes. Genes Dev. 1998, 12, 1763-1768. [CrossRef] [PubMed] 
84. Matsuoka, T.-A.; Artner, I.; Henderson, E.; Means, A.; Sander, M.; Stein, R. The MafA transcription factor appears to be responsible for tissue-specific expression of insulin. Proc. Natl. Acad. Sci. USA 2004, 101, 2930-2933. [CrossRef]

85. Matsuoka, T.-A.; Zhao, L.; Artner, I.; Jarrett, H.W.; Friedman, D.; Means, A.; Stein, R. Members of the Large Maf Transcription Family Regulate Insulin Gene Transcription in Islet $\beta$ Cells. Mol. Cell. Biol. 2003, 23, 6049-6062. [CrossRef] [PubMed]

86. Samaras, S.E.; Zhao, L.; Means, A.; Henderson, E.; Matsuoka, T.-A.; Stein, R. The Islet beta Cell-enriched RIPE3b1/Maf Transcription Factor Regulates pdx-1 Expression. J. Biol. Chem. 2003, 278, 12263-12270. [CrossRef] [PubMed]

87. Gunton, J.E.; Kulkarni, R.N.; Yim, S.; Okada, T.; Hawthorne, W.J.; Tseng, Y.-H.; Roberson, R.S.; Ricordi, C.; O'Connell, P.J.; Gonzalez, F.J.; et al. Loss of ARNT/HIF1 $\beta$ Mediates Altered Gene Expression and Pancreatic-Islet Dysfunction in Human Type 2 Diabetes. Cell 2005, 122, 337-349. [CrossRef]

88. Norquay, L.D.; D'Aquino, K.E.; Opare-Addo, L.M.; Kuznetsova, A.; Haas, M.; Bluestone, J.A.; White, M.F. Insulin Receptor Substrate-2 in $\beta$-Cells Decreases Diabetes in Nonobese Diabetic Mice. Endocrinology 2009, 150, 4531-4540. [CrossRef]

89. Johnson, J.D.; Bernal-Mizrachi, E.; Alejandro, E.; Han, Z.; Kalynyak, T.B.; Li, H.; Beith, J.L.; Gross, J.; Warnock, G.L.; Townsend, R.R.; et al. Insulin protects islets from apoptosis via Pdx1 and specific changes in the human islet proteome. Proc. Natl. Acad. Sci. USA 2006, 103, 19575-19580. [CrossRef]

90. Escribano, Ó.; Gomez-Hernandez, A.; Diaz-Castroverde, S.; Nevado, C.; García, G.; Otero, Y.F.; Perdomo, L.; Beneit, N.; Benito, M Insulin receptor isoform A confers a higher proliferative capability to pancreatic beta cells enabling glucose availability and IGF-I signaling. Mol. Cell. Endocrinol. 2015, 409, 82-91. [CrossRef]

91. Boucher, J.; Kleinridders, A.; Kahn, C.R. Insulin Receptor Signaling in Normal and Insulin-Resistant States. Cold Spring Harb. Perspect. Biol. 2014, 6, a009191. [CrossRef] [PubMed]

92. Carter, J.D.; Dula, S.B.; Corbin, K.L.; Wu, R.; Nunemaker, C.S. A Practical Guide to Rodent Islet Isolation and Assessment. Biol. Proced. Online 2009, 11, 3-31. [CrossRef] [PubMed]

93. Zardooz, H.; Asl, S.Z.; Naseri, M.G. Effect of chronic psychological stress on insulin release from rat isolated pancreatic islets. Life Sci. 2006, 79, 57-62. [CrossRef]

94. Zardooz, H.; Zahediasl, S.; Rostamkhani, F.; Farrokhi, B.; Nasiraei, S.; Kazeminezhad, B.; Gholampour, R. Effects of acute and chronic psychological stress on isolated islets' insulin release. EXCLI J. 2012, 11, 163-175.

95. Gray, S.M.; Page, L.C.; Tong, J. Ghrelin regulation of glucose metabolism. J. Neuroendocr. 2019, 31, e12705. [CrossRef] [PubMed]

96. Kim, W.; Fiori, J.L.; Shin, Y.-K.; Okun, E.; Kim, J.S.; Rapp, P.R.; Egan, J.M. Pancreatic polypeptide inhibits somatostatin secretion. FEBS Lett. 2014, 588, 3233-3239. [CrossRef] [PubMed]

97. Park, H.J.; Lee, Y.L.; Kwon, H.Y. Effects of pancreatic polypeptide on insulin action in exocrine secretion of isolated rat pancreas. J. Physiol. 1993, 463, 421-429. [CrossRef]

98. Egido, E.M.; Rodriguez-Gallardo, J.; Silvestre, R.A.; Marco, J. Inhibitory effect of ghrelin on insulin and pancreatic somatostatin secretion. Eur. J. Endocrinol. 2002, 146, 241-244. [CrossRef]

99. Mani, B.K.; Shankar, K.; Zigman, J.M. Ghrelin's Relationship to Blood Glucose. Endocrinology 2019, 160, 1247-1261. [CrossRef]

100. Wren, A.M.; Small, C.J.; Ward, H.L.; Murphy, K.G.; Dakin, C.L.; Taheri, S.; Kennedy, A.R.; Roberts, G.H.; Morgan, D.G.; Ghatei, M.A.; et al. The novel hypothalamic peptide ghrelin stimulates food intake and growth hormone secretion. Endocrinology 2020, 14, 4325-4328. [CrossRef]

101. Arosio, M.; Ronchi, C.L.; Gebbia, C.; Cappiello, V.; Beck-Peccoz, P.; Peracchi, M. Stimulatory Effects of Ghrelin on Circulating Somatostatin and Pancreatic Polypeptide Levels. J. Clin. Endocrinol. Metab. 2003, 88, 701-704. [CrossRef]

102. Yin, T.C.; Bauchle, C.J.; Rouault, A.A.; Stephens, S.B.; Sebag, J.A. The Insulinostatic Effect of Ghrelin Requires MRAP2 Expression in $\delta$ Cells. Iscience 2020, 23, 101216. [CrossRef] [PubMed]

103. Baldanzi, G.; Filigheddu, N.; Cutrupi, S.; Catapano, F.; Bonissoni, S.; Fubini, A.; Malan, D.; Baj, G.; Granata, R.; Broglio, F.; et al. Ghrelin and des-acyl ghrelin inhibit cell death in cardiomyocytes and endothelial cells through ERK1/2 and PI 3-kinase/AKT. J. Cell Biol. 2002, 159, 1029-1037. [CrossRef] [PubMed]

104. Thompson, N.; Gill, D.A.S.; Davies, R.; Loveridge, N.; Houston, P.A.; Robinson, I.C.A.F.; Wells, T. Ghrelin and Des-Octanoyl Ghrelin Promote Adipogenesis Directly in Vivo by a Mechanism Independent of the Type 1a Growth Hormone Secretagogue Receptor. Endocrinology 2004, 145, 234-242. [CrossRef] [PubMed]

105. Delhanty, P.J.D.; van der Eerden, B.; Van Der Velde, M.; Gauna, C.; Pols, H.A.P.; Jahr, H.; Chiba, H.; Van Der Lely, A.J.; Van Leeuwen, J.P.T.M. Ghrelin and unacylated ghrelin stimulate human osteoblast growth via mitogen-activated protein kinase (MAPK)/phosphoinositide 3-kinase (PI3K) pathways in the absence of GHS-R1a. J. Endocrinol. 2006, 188, 37-47. [CrossRef]

106. Van Der Meulen, T.; Donaldson, C.J.; Caceres, E.; Hunter, A.E.; Cowing-Zitron, C.; Pound, L.D.; Adams, M.W.; Zembrzycki, A.; Grove, K.L.; Huising, M.O. Urocortin3 mediates somatostatin-dependent negative feedback control of insulin secretion. Nat. Med. 2015, 21, 769-776. [CrossRef]

107. Shankar, K.; Takemi, S.; Gupta, D.; Varshney, S.; Mani, B.K.; Osborne-Lawrence, S.; Metzger, N.P.; Richard, C.P.; Berglund, E.D.; Zigman, J.M. Ghrelin cell-expressed insulin receptors mediate meal- and obesity-induced declines in plasma ghrelin. JCI Insight 2021, 6, e146983. [CrossRef] 